\title{
Sosyal Bilgiler Öğretmenlerinin TÜBітAK 4006 Proje Deneyimlerinden Yansımalar: Sorunlar ve Çözüm Önerileri
}

\section{Reflections from Social Studies Teachers' TÜBITAK 4006 Project Experiences: Problems and Solution Suggestions}

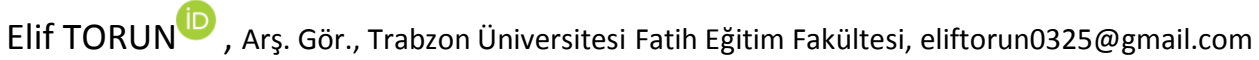

Mehmet AKPINAR ，Doç.Dr., Trabzon Üniversitesi Fatih Eğitim Fakültesi, makpınar66@yahoo.com

\begin{abstract}
Torun, E. ve Akpınar, M.(2021). Sosyal Bilgiler Öğretmenlerinin TÜBiTAK 4006 Proje Deneyimlerinden Yansımalar: Sorunlar ve Çözüm Önerileri. Batı Anadolu Eğitim Bilimleri Dergisi, 12(2), 717-741.
\end{abstract}

Öz. Bu araştırmanın amacı, sosyal bilgiler öğretmenlerinin Türkiye Bilimsel ve Teknolojik Araştırma Kurumu (TÜBITAK) 4006 proje süreçlerine dair görüşlerini ve bu süreçte karşılaştıkları sorunları ve bu sorunlara önerdikleri çözümleri ortaya koymaktır. Çalışma nitel araştırma yöntemlerinden durum araştırması olarak yürütülmüştür. Araştırmanın çalışma grubu, amaçlı örneklemenin ölçüt ve kartopu örnekleme deseni ile belirlenmiştir. Bu bağlamda Türkiye'nin farklı illerinden 19'u erkek, 11'i kadın olmak üzere 30 sosyal bilgiler öğretmeni çalışma grubuna dahil edilmiştir. Mülakat tekniğinin kullanıldığı çalışmada veriler, telefon, internet ve yazılı form aracılığıyla toplanmıştır. Çalışmadan elde edilen veriler içerik analizine tabi tutulmuştur. Öğretmenlerin sosyal bilimler alanlarındaki konu başlıklarını yetersiz bulmaları, maket -model yapımında yetersiz kalmaları, proje çalışmalarına çoğunlukla gönüllü katılmamaları, motivasyonlarının düşük olması ve öğrenci düzeyini yetersiz görmeleri çalışmanın sonuçlarındandır. Öğretmenlerin en çok dile getirdikleri çözüm önerisinin proje katılımının gönüllülük esasınca yapılması, proje konuları hakkında kendilerine rehberlik edebilecek kişilere ulaşabilme, proje çalışmaları hakkında bilgilendirici faaliyetlerin düzenlenmesidir. Öğretmenler sorun olarak sundukları durumlara ilişkin daha az çözüm önerisi getirmesi çalışmanın dikkat çeken sonuçlarındandır. TÜBITAK 4006 proje konu başlıkları arasında sosyal bilim konularının artırılması, öğretmenleri projeye teşvik edici seminer ve çalışmaların yaygınlaştırılması ve proje çalışmalarının önemini vurgulayan faaliyetler düzenlenmesi önerilmektedir.

Anahtar Kelimeler: Türkiye bilimsel ve teknolojik araştırma kurumu, TÜBiTAK_4006, Bilim fuarı, Sosyal bilgiler öğretmenleri

\begin{abstract}
The aim of this research is to reveal the opinions of social studies teachers about the Scientific and Technological Research Council of Turkey (TÜBITAK) 4006 project processes, the problems they encounter in this process and the solutions they propose to these problems. The study was conducted as a case study, one of the qualitative research methods. The study group of the research was determined by the criterion and snowball sampling design of purposive sampling. In this context, 30 social studies teachers, 19 male and 11 female, from different provinces of Turkey were included in the study group. In the study in which the interview technique was used, the data were collected via telephone, internet and written form. The data obtained from the study were subjected to content analysis. The teachers' finding insufficient topics in social sciences, their inadequacy in model making, the fact that they do not participate in project studies voluntarily, their motivation is low, and they see the student level as insufficient are among the results of the study. The most frequently mentioned solution proposal by the teachers is making the participation in the project on a voluntary basis, reaching the people who can guide them about the project issues, and organizing informative
\end{abstract}


activities about the project studies. It is one of the remarkable results of the study that teachers offer fewer solutions for the situations they present as problems. Among TÜBITAK 4006 project topics, it is recommended to increase social science topics, disseminate seminars and studies that encourage teachers to participate in the project, and organize activities emphasizing the importance of project studies.

Keywords: The Scıentıfıc and technologıcal research councıl of turkey, TÜBITAK 4006, Science exhibition, Social studies eachers 


\section{Extended Abstract}

Introduction. In addition to the fact that the individual acquires life-oriented skills, gains a scientific perspective, and develops problem-solving skills, this issue is also emphasized in the social studies curriculum. In the title of issues to be considered in the implementation of the program, it is emphasized that social studies as social sciences and social studies approaches as reflective thinking are at the forefront (MEB,2018). It can be said that the basic philosophy of this approach is to provide students with a scientific perspective and to gain problem solving skills by comparing them with real life problems. In addition, it can be said that project-based teaching will provide an important opportunity for both achieving social studies course gains and reaching the final goal. TÜBITAK 4006 program can be considered as an important support program for producing projects and presenting products. However, as a result of the research, it was noticed that the participation in TÜBITAK 4006 projects in the field of social studies is low. Considering the low number of applications for project studies in the field of social studies, the reason for the low number of project studies in this field was determined. In addition, although the 4006-TUBITAK science fair is a comprehensive program carried out in primary, secondary and secondary education throughout Turkey, it has been observed that limited research has been done on the subject. In this context, in this study, it is aimed to reveal the problems and solution proposals experienced in this process by taking the opinions of the social studies teachers who have TÜBITAK 4006 project experience on the project processes. It is thought that this study may be important in terms of recognizing the situations that may prevent the production of projects in the field of social studies, revealing the problems of academicians, teachers and officials working in the field and teachers working in the field of social studies in producing projects, offering solutions and shedding light on the solution of the problems experienced in this context.

Method. This study was conducted as a case study from qualitative research methods. The study group of the research consisted of 35 social studies teachers, 19 male and 16 female, working in various provinces of Turkey in the spring term of the 2020-2021 academic yearln the study, easily accessible situation and snowball patterns of the purposeful sampling method, which is one of the selective sampling methods, were used. In this context, in the first place, Trabzon R\&D unit was contacted and contact information was obtained with the consent of the social studies teachers with TÜBITAK 4006 project experience. After interviewing the teachers who were informed about the purpose and scope of the study and those who wanted to participate in the study, the working group was expanded by requesting the contact information of the teachers they thought could be involved in the study. In the study, semi-structured interview form was used as a data collection tool. The form prepared by the researchers was first sent to the field and language specialist, and the form was shaped in line with the feedback from the experts. Data were collected through an interview form consisting of 18 questions covering demographic information and teachers' TÜBITAK 4006 project processes, the problems they encountered in this process, and solution suggestions. Content analysis was applied to the data, codes and themes were presented as figures.

Results. According to the results obtained from the study, it can be stated that social studies teachers are insufficient in choosing a subject and scanning the literature. Project topics are mostly 
determined by teachers. Social studies teachers do not consider the topics listed among the Science Fair Thematic Sub-Project Areas on the TUBITAK site to be sufficient in terms of social studies, and therefore have problems in determining the topic. The teachers do not voluntarily participate in the project work. Social studies teachers think that the TÜBITAK 4006 project process benefits them in terms of encouraging research, external motivation, and gaining cognitive and affective skills. Teachers see that the most important contribution of the TÜBITAK 4006 project process to society is the awareness of science in the eyes of society. Again, teachers consider the academic and emotional contribution of the TÜBITAK 4006 project process to the students as the most important contribution.

Discussion and Conclusion. When the results obtained from the study are evaluated in general, it can be stated that there are a few topics that do not overlap with the literature and the field-specific problems experienced by social studies teachers during the TÜBITAK 4006 project process. It is one of the remarkable results of the study that social science subjects are less involved in choosing a subject, teachers are insufficient in making models and other courses draw more attention in this context. In addition, it is one of the important results of the study that the teachers did not offer solutions as much as they voiced the problems. Based on the results of the research, it was found that school administrators do not encourage teachers and students about projects. In this context, school administrators encouraging teachers and students to work on projects can pave the way for the preparation of more qualified, original and purposeful projects. An official platform can be established to meet with experts in the field and people with project experience in the digital environment. Thus, it can be ensured that teachers and students who have problems in areas such as project idea creation, writing and implementation can communicate with people in different places. 


\section{Giriş}

Bireyin öğrenmesinin yanı sıra öğrendiklerini yaşama aktarıp hayata dönük olarak kullanmasını sağlamak eğitim öğretim faaliyetlerinin yürütüldüğü okulların önemli görevleri arasındadır. Nitekim yaşama aktarılamayan bilginin pratikte öğrenciye faydası olmayacak ve böylesi bir bilgi zihinsel yükten öteye gitmeyecektir. Dewey okullar hayatın laboratuvarları gibi olması gerektiği ve öğrencilerin burada edindikleri bilgi ve tecrübelerle hayata atılması gerektiğini vurgular. Okullar bireye yaşama dönük bilgi ve beceri kazandırma adına farklı model, strateji, yöntem ve teknikler benimsenmektedir (Çelikkaya ve Kuş, 2009; Eskici, 2017). Bu modellerden biri olan ve Dewey tarafından geliştirilen Proje Tabanlı Öğrenme Modeli (PTÖM) bireyin öğrendiklerini yaşama aktarma ve hayata dönük somut tecrübeler edinme adına önemli bir fırsat sunmaktadır. Geçmişten günümüze yapılan birçok çalışmada projelerin sunulduğu bilim fuar, şenlik ve olimpiyatların öğrencilerin yaşama dönük beceri edinmesi adına önemli olduğu belirtilmiştir. Bunun yanı sıra PTÖM ile ortaya konan projeler, düzenlenen bilim fuarları öğrencilerde bilimsel düşünme becerilerini geliştirdiği, araştırmaya isteklilik oluşturduğu, sorgulama ve bilime yönelik kariyer planlamasında aktif rol oynadığı çeşitli çalışmalarda da vurgulanmıştır (Bruce ve Bruce, 2000; Bunderson ve Anderson, 1996; Fisanick, 2010; Dionne, Reis, Trudel, Guillet, Kleine, ve Hancianu, 2012, Okuyucu, 2019). Schneider ve Lumpe (1996) yaptığı çalışmada bilimsel projeler sayesinde öğretmenlerin öğrencilere üst düzey düşünme ve sorgulama becerilerini kazandırabileceklerini vurgulamıştır. Bu bulgu birçok çalışma ile de desteklenmiştir. Avcl, Su-Özenir ve Yücel (2016), Jensen ve Buckley (2014), Sözer (2017) proje çalışmalarının öğrencilerin analiz yeteneği, analitik düşünme becerileri gibi üst düzey düşünme becerilerinin yanı sıra sosyal becerileri de desteklediğini ifade etmiştir. Derslerin proje destekli olarak yürütülmesi öğrencilerin derse yönelik tutumlarını da olumlu yönde etkilemektedir (Durmaz, Oğuzhan-Dinçer ve Osmanoğlu, 2017; Finnerty, 2013; Sülün, Ekiz ve Sülün, 2009).

Bilim ve bilginin halka mal edilmesi, bilginin daha geniş kitlelere ulaşması adına projeler ve bu projelerin hazırlanması, sunumu ve hedef kitleye ulaştırılması adına bazı kurum ve kuruluşlar önem taşımaktadır. Bu kuruluşlardan biri de TÜBіTAK'dır. TÜBITAK bilim ile halkı buluşturmayı hedefleyen, bilginin daha geniş kitlelere ulaşması adına önemli rol oynayan ve 1963 yılından bu yana faaliyet gösteren bir kurumdur. Bu hedefle TÜBITAK amaç ve içeriğine göre farklı programlar vasıtasıyla bilim gönüllülerine destek sağlamaktadır. TÜBITAK okullardaki bilimsel faaliyetleri geliştirmek ve desteklemek için de farklı programları barındırmaktadır. Bu programlardan biri de 4006-TÜBITAK Bilim Fuarları Destekleme Programı'dır.

TÜBITAK 4006 programı doğrudan okul ve öğrencilere hitap ettiği için eğitim alanında ayrı bir öneme sahiptir. Diğer TÜBITAK 4006 Bilim Fuarları Destekleme Programı 4000 kodlu projelerden öğrencilerin ön plana çıkmasıyla farklılaşmaktadır. 4006 TÜBiTAK programı, "Eğitimde iş̧ Birliği Protokolü" kapsamında MEB-TÜBiTAK arasında imzalanan ve bilim kültürünü geniş kitlelere okul ve eğitim vasıtasıyla yayma amacıyla ortaya çıkmıştır. Bu bağlamda 5-12 sınıflar düzeyinde eğitim gören öğrencilerin bilimsel faaliyete teşvik, bilimsel araştırma yapma bilgi ve becerilerinin kazandırılması, iş birliği ile proje üretme, sunma olanaklarını destekleyici ortam ve olanakların sağlandığı bir programdır. Bu program öğrencilerin bilimsel faaliyetlere araştırarak, sorgulayarak ve çözüm üreterek dahil olmasını bilişsel, duyuşsal, psikomotor gelişmeyi mümkün kılmayı amaçlar. TÜBiTAK 4006 programı öğrencilerin yaparak ve yaşayarak öğrenmelerine olanak sağlamaktadır. Belirlenen 43 tematik alandan en az 5 tanesini içeren konular üzerinde çalışma yapılması beklenmektedir. 2013 yılında başlayan programda, araştırma, inceleme ve tasarım alt türlerinde projeler desteklenmektedir. TÜBiTAK web sitesinde proje çalışmalarıyla desteklenen eğitimin; öğrencilerin bilimsel çalışma yapmaya teşvik edilerek bilimsel beceri geliştirmesi, farklı öğrenme stillerine sahip her seviyedeki öğrenciyi proje hazırlayarak sürecine dahil edilmesi, öğrencilerin araştırma yapma, yürütme, sonuçlandırma ve sunma becerilerini geliştirmesi, öğrencilerde işbirliği becerisi geliştirerek 
ortak proje hazırlama olanaklarını sağlaması, bilimsel araştırma ile gerçek hayat problemlerine yaparak ve yaşayarak çözüm bulma becerisi geliştirmesi gibi faydalarından bahsedilmektedir (Web 1):

Bireyin hayata dönük beceriler edinmesi, bilimsel bakış açısı kazanması, problem çözme becerilerinin geliştirilmesi birçok öğretim programında ön plana çıkarılmasının yanında sosyal bilgiler öğretim programında da bu hususa dikkat çekilmektedir. Nitekim programın uygulamasında dikkat edilecek hususlar başlı̆ında sosyal bilimler olarak sosyal bilgiler ve yansıtıcı düşünme olarak sosyal bilgiler yaklaşımlarının ön planda olması vurgulanmaktadır (MEB,2018). Bu yaklaşımın temel felsefesinin öğrencilere bilimsel bakış açısı kazandırmanın ve öğrencileri gerçek yaşam problemleri ile karşılaştırarak problem çözme becerisi kazandırmak olduğu söylenebilir. Bu bağlamda proje tabanlı öğretimin hem sosyal bilgiler ders kazanımlarına ulaşma hem de nihai hedefe ulaşma adına önemli bir fırsat sunacağı söylenebilir. Bu bağlamda TÜBITAK 4006 programı proje üretme ve ürünlerin sunulması için önemli bir destek programı olarak düşünülebilir. 2020 yılında 30 farklı tematik alandan 12.832 okulun sunduğu 240.852 alt proje için başvuruda bulunulmuş bu projelerden 124.401 alt proje destek almaya hak kazandığı açıklanmıştır. Ancak yapılan araştırma sonucu sosyal bilgiler alanında TÜBiTAK 4006 projelerine katılımın az olduğu fark edilmiştir. Bu hususla ilgili olarak fen bilimleri alanında TÜBITAK projeleri ve TÜBITAK 4006 programı özelinde yapılan birçok çalışmanın bulunduğu söylenebilir. Fen bilimleri alanında proje programlarına katılım artırmak ve sorunları tespit etmek adına bir çok çalışma bulunmasına rağmen (Oğuz Ünver, Arabacıoğlu ve Okulu (2015); Özel ve Akyol (2016), Bolat, Bacanak, Kaşıkçı ve Değirmenci (2014), Çavuş, Balçın ve Yılmaz (2018), Tortop (2013) Avcı vd. (2016), Jensen ve Buckley (2014), Sözer (2017); Çetin ve Şengezer (2016 Dionne vd. (2012) ve Kubinova, Novotna ve Littler (1999) Baki ve Bütüner (2009), Fallik, Eylon ve Rosenfeld (2008) ve Windschitl (2003) Durmaz vd. (2017), Finnerty (2013) ve Sülün vd. (2009), Keçeci, 2017; Tortop, 2014, Yıldırım ve Şensoy, 2016) Kankelborg, 2005) Bunderson ve Anderson (1996), Grote (1995) sosyal bilgiler alanında bu tür bir çalışmaya rastlanmamıştır. Sosyal bilgiler alanında proje çalışmalarına başvurunun az oluşu dikkate alınarak bu alanda proje çalışmalarının az olmasının nedeni tespit edilmek istenmiştir. Ayrıca 4006-TÜBiTAK bilim fuarı Türkiye çapında ilköğretim ikinci ve ortaöğretim kademede gerçekleştirilen kapsamlı bir program olmasına rağmen konuya ilişkin sınırlı sayıda araştırmaların (Durmaz vd., 2017; Keçeci, 2017; Tortop, 2014, Yıldırım ve Şensoy, 2016) yapıldığı gözlemlenmiştir. Bu bağlamda bu çalışmada TÜBITAK 4006 proje deneyimi olan sosyal bilgiler öğretmenlerinin proje süreçlerine dair görüşleri alınarak, bu süreçte yaşadıkları sorunları ve çözüm önerilerini ortaya koymak amaçlanmıştır. Bu çalışmanın sosyal bilgiler alanında proje üretimine engel olabilecek durumlar adına fırsat sunacağı, alanda çalışan akademisyen, öğretmen ve yetkililerle sosyal bilgiler alanında çalışan öğretmenlerin proje üretme hususundaki sorunlarını ortaya koyma, çözüm sunma ve bu bağlamda yaşanılan sorunların çözümü için ışık tutması adına önem taşıyabileceği düşünülmektedir. Bu hedefle araştırmanın problem cümlesi "Sosyal Bilgiler öğretmenlerinin TÜBITAK 4006 proje deneyimlerine ilişkin görüşleri nelerdir?" olarak belirlenirken, araştırmanın alt problemleri aşağıdaki gibidir.

1.Sosyal bilgiler öğretmenlerinin TÜBITAK 4006 projelerini oluştururken hazırlık, uygulama ve değerlendirme sürecinde karşılaştıkları sorunlar ve çözümüne ilişkin görüşleri nelerdir?

2.Sosyal bilgiler öğretmenlerinin TÜBITAK 4006 Projelerine katılma amaçları ve bu amaçları gerçekleştirme durumlarına ilişkin görüşleri nelerdir?

3.Sosyal bilgiler öğretmenlerinin 4006 TÜBITAK projelerinin kendilerine, topluma ve öğrencilere katkılarına ilişkin görüşleri nelerdir?

\section{Yöntem}

Bu bölümde araştırmanın modeli, çalışma grubu, veri toplama aracı, veri toplama süreci ve veri analizine ilişkin bilgiler verilmiştir. 


\section{Araştırmanın Modeli}

Sosyal bilgiler öğretmenlerinin TÜBITAK 4006 proje süreçlerine dair görüşlerini ve bu süreçte karşılaştıkları sorunları ve bu sorunlara önerdikleri çözümleri ortaya koymanın amaçlandığı bu çalışma nitel araştırma yöntemlerinden durum çalışması olarak yürütülmüştür. Durum çalışması çeşitli konuları anlamak ve detaylı açıklanması için ne, nasıl, niçin sorularına yanıt arandığı bir yöntemdir (Çepni, 2014). Çalışmada sosyal bilgiler öğretmenlerinin proje sürecinde yaşadıkları durumlar detaylı olarak ele alındığı için bu yöntem tercih edilmiştir.

\section{Çalışma Grubu}

Bu araştırmanın çalışma grubunu 2020-2021 eğitim-öğretim yılı bahar döneminde Türkiye'nin çeşitli illerinde görev yapan 19'u erkek 16'sı kadın olmak üzere 35 sosyal bilgiler öğretmeni oluşturmuştur. Çalışmada seçkili örnekleme yöntemlerinden amaçlı örnekleme yönteminin kolay ulaşılabilir durum ve kartopu desenleri kullanılmıştır. Bu bağlamda ilk etapta Trabzon Ar-ge birimi ile iletişime geçilerek TÜBITAK 4006 proje deneyimi olan sosyal bilgiler öğretmenlerinin rızaları dahilinde iletişim bilgileri alınmıştır. Çalışma amaç ve kapsamı hakkında bilgilendirilen öğretmenlerden çalışmaya katılım göstermek isteyenlerle görüşüldükten sonra çalışmaya dahil olabileceğini düşündükleri öğretmenlerin iletişim bilgileri talep edilerek çalışma grubu genişletilmiştir. 8 farklı ilden çalışma grubuna dahil edilen sosyal bilgiler öğretmenlerinin 3'ü doktora 12'si yüksek lisans 20'si lisans eğitimi mezunudur. Öğretmenlerin 27'si devlet okulu, 4'ü özel okul ve 4'ü Bilsem kurumunda görev yapmaktadır. Öğretmenlerden 9'unun idari görevi bulunmaktadır. Öğretmenlerin bir 8'i hizmet öncesi, 9'u hizmet içi eğitimlerle proje türleri ve hazırlık sürecine dair eğitim aldığını ifade ederken, $13^{\prime u ̈ ~ p r o j e ~ c ̧ a l ı s ̧ m a l a r ı ~ h a k k ı n d a ~ e g ̆ i t i m ~ a l m a d ı g ̆ ı n ı ~ b e l i r t m i s ̧ t i r . ~}$

\section{Veri Toplama Aracı}

Çalışmada veri toplama aracı olarak yarı yapılandırımış görüşme formundan yararlanılmıştır. Görüşme formu hazırlanmadan önce araştırma problemine cevap oluşturabilecek sorulardan soru havuzu oluşturulmuştur. Birbirini kapsayan ve araştırma problemi dışına çıkan sorular ayıklanarak görüşme formu oluşturulmuştur. Oluşturulan görüşme formu TÜBITAK proje deneyimi olan 3'ü akademisyen $5^{\prime} i$ öğretmen olmak üzere 8 sosyal bilgiler alan uzmanının görüşüne sunulmuştur. Alan uzmanlarından gelen dönütler doğrultusunda 22 olan soru sayısı azaltılarak aynı doğrultuda olduğu düşünülen sorular formdan çıkartılmış ve proje oluşturma sürecinin sırası dikkate alınarak soruların sıralamasında düzeltmeler yapılmıştır. Bu anlamda proje hazırlık sürecinden değerlendirme sürecine doğru sorular sıralanmış ardından amaç ve projenin katkılarına ilişkin görüşlerine yönelik sorulara yer verilmiştir. Daha sonra form dil ve anlaşılırlık yönünden incelemesi için dil uzmanına gönderilmiştir. Dil uzmanından gelen dönütler doğrultusunda cinsiyet, mesleki kıdem, eğitim durumu, kurumdaki görev gibi demografik bilgilerin yer aldığı ve öğretmenlerin TÜBіTAK 4006 proje süreçleri ile bu süreçte karşılaştıkları sorunlar ve çözüm önerilerini kapsayan 18 sorudan oluşan görüşme formuna nihai şekli verilmiştir.

\section{Veri Toplama Süreci}

Çalışmanın veri toplama süreci etik kurul onayı alındıktan sonra başlatılmıştır. Bu bağlamda çalışmanın etik kurul incelemesi Trabzon Üniversitesi Sosyal ve Beşeri Bilimler Bilimsel Araştırma ve Yayın Etik Kurulu tarafından yapılmış ve 19.02.2021 tarih "E-81614018-000-157" sayılı karar ile çalışmanın yapılması etik olarak uygun bulunmuştur. Çalışmada nitel yaklaşım benimsenerek veriler görüşme tekniğiyle toplanmıştır. Çalışma grubunun özellikleri belirlenmesinin ardından Trabzon MEB Ar-Ge birimi ile iletişime geçilmiş ve yapılacak çalışma kapsamından bahsedilerek TÜBITAK 4006 proje deneyimi olan öğretmenlerin rızaları dahilinde iletişim bilgileri talep edilmiştir. Iletişime geçilen 
öğretmenler çalışma amaç ve kapsamı hakkında bilgilendirilmiş ve gönüllülük esasına göre çalışma kapsamında görüşme için randevu alınmıştır. Bu bağlamda öğretmenler ile telefon ve video konferans aracılığıyla mülakatlar gerçekleştirilmiştir. Öğretmenlerin onayı doğrultusunda ses-video ve elektronik form ile görüşmeler kayıt altına alınmıştır. Görüşme kayıtları, araştırmacıların kişisel flash belleklerinde ve online veri depolama hesaplarında olmak üzere ayrı platformlarda depolanarak saklanmıştır.

Çalışmaya katılmayı kabul eden öğretmenlerden çalışmaya dahil olabileceğini düşündükleri öğretmenlerin rızaları dahilinde isim ve iletişim bilgileri talep edilerek çalışma grubu kartopu tekniğiyle genişletilmiştir. Her bir katılımcı ile görüşme ortalama 20-30 dakika sürmüştür. Katılımcıların sorulara birbirini tekrar eden, benzer cevaplar vermesi- ve farklı görüşlerin olmaması veri doygunluğuna ulaşıldığına dair kanaat oluşturduğu aşamada veri toplama süreci sona erdirilmiştir (Yıldırım ve Şimşek, 2008).

\section{Verilerin Analizi}

Araştırmanın amacı doğrultusunda çalışmaya dahil olabilecek öğretmenler ile iletişime geçilerek araştırmanın kapsamı hakkında verilmiş ve çalışmaya katılmaya davet edilmiştir. Katılımcılara mülakata istedikleri an son verebilecekleri, bilgilerinin yalnızca bilimsel amaçla kullanılacağı bildirilmiştir. Ayrıca kimlik bilgilerinin gizli tutulacağı ve görüşlerinin temsili kodlarla çalışmada yer alacağı bilgisi verilmiştir. Gönüllülük esasına göre çalışmaya katılmayı kabul eden öğretmenlerden randevu alınarak kendileri için uygun gün ve saatlerde mülakatlar yapılmıştır. Mülakatların nasıl yapılacağı katılımcıların rızalarına bırakılmıştır. Pandemi koşulları nedeniyle yüz yüze gerçekleştirilemeyen mülakatlar yoğunlukla telefon ve internet aracılığıyla yapılmıştır. Toplanan veriler iki araştırmacı tarafından hem flash bellek hem de online veri depolama hesaplarında saklanmıştır. Veri analiz aşamasında öncelikle mülakatta ses ve görüntü kaydı alınmasını onaylayan öğretmenlerin görüşleri transkript edilerek yazıya aktarılmıştır. Ortalama 20-30 dakika süren görüşmelerin transkripti yaklaşık bir ay sürede gerçekleştirilmiştir. Transkript edilen veriler, elektronik form aracılığıyla toplanan veriler ile birleştirilerek içerik analizine tabi tutulmuştur. Bu bağlamda öncelikle katılımcıların araştırma sorularına yanıt oluşturabilecek görüşleri diğer ifadelerinden ayıklanmış ve araştırma konusuyla ilgili olan ifadeler birinci araştırmacı tarafından kodlanmıştır. Kodlanan veriler daha sonra ilgili temalar altında birleştirilmiştir. Örneğin, "Sosyal bilgilerde proje yapmaya elverişli konu az bu bizi zorlamıştı" (KÖ20) ifadesi "Sosyal Bilgiler'deki konuların az olması" kodu ile program kaynaklı sorun teması ile sunulmuştur. Katılımcıların kodlanan ve tema altında birleştirilen görüşleri birinci araştırmacı tarafından ayrı bir dosyaya kaydedilerek ikinci araştırmacıya sunulmuştur. Oluşturulan kod ve temaların ikinci araştırmacı tarafından teyit edilmesinin ardından içerik analizinde uzman olan iki akademisyenin daha analiz hakkında görüşüne başvurulmuştur.. Uzmanların yapılan analizi doğru olarak nitelendirmesi ve kendilerinin de benzer kod ve temalara yer verebileceği yönünde görüş bildirmeleriyle geçerlik ve güvenirlik üzerine büyük oranda uzlaşım sağlanmıştır. Temelde kod ve temalar değişmemekle birlikte ifade yönünden yeniden düzenlenmesi gerekli görülen kodlar üzerine de görüş bildiren uzmanların dönütleri doğrultusunda veri analizine son şekli verilmiştir. Veri analizi sonrasında elde edilen bulgular şekiller halinde sunulmuş, bulgular doğrudan alıntılarla desteklenerek yorumlanmıştır. Doğrudan alıntılarda katılımcılardan kadın öğretmenler için KÖ erkek öğretmenler için EÖ kodları numaralandırılarak görüşlere yer verilmiştir. Çalışmada öğretmen ifadesi sosyal bilgiler öğretmenleri yerine kullanılmış farklı branşlardaki öğretmenler kastedildiğinde ilgili branş ifadesine yer verilmiştir. Yine çalışmada proje ifadesi TÜBITAK 4006 projeleri yerine kullanılmış olup farklı projelerden bahsedilirken ilgili proje koduna yer verilmiştir. 


\section{Bulgular}

Bu bölümde sosyal bilgiler öğretmenlerinin TÜBiTAK 4006 proje süreçlerine dair görüşleri analiz edilmiştir. Elde edilen bulgular şekiller kullanılarak görselleştirilmiş ve kodlar görüş sayısını ifade eden frekans bilgileriyle sunulmuştur. Katılımcıların görüşleri gerçek isimleri yerine kodlar kullanılarak doğrudan alıntılarla sunulmuştur.

\section{Birinci Alt Probleme ilişkin Bulgular}

Sosyal bilgiler öğretmenlerinin TÜBITAK 4006 projelerini oluştururken hazırlık, uygulama ve değerlendirme sürecinde karşılaştıkları sorunlar ve çözümüne ilişkin görüşleri Şekil 1'de sunulmuştur.

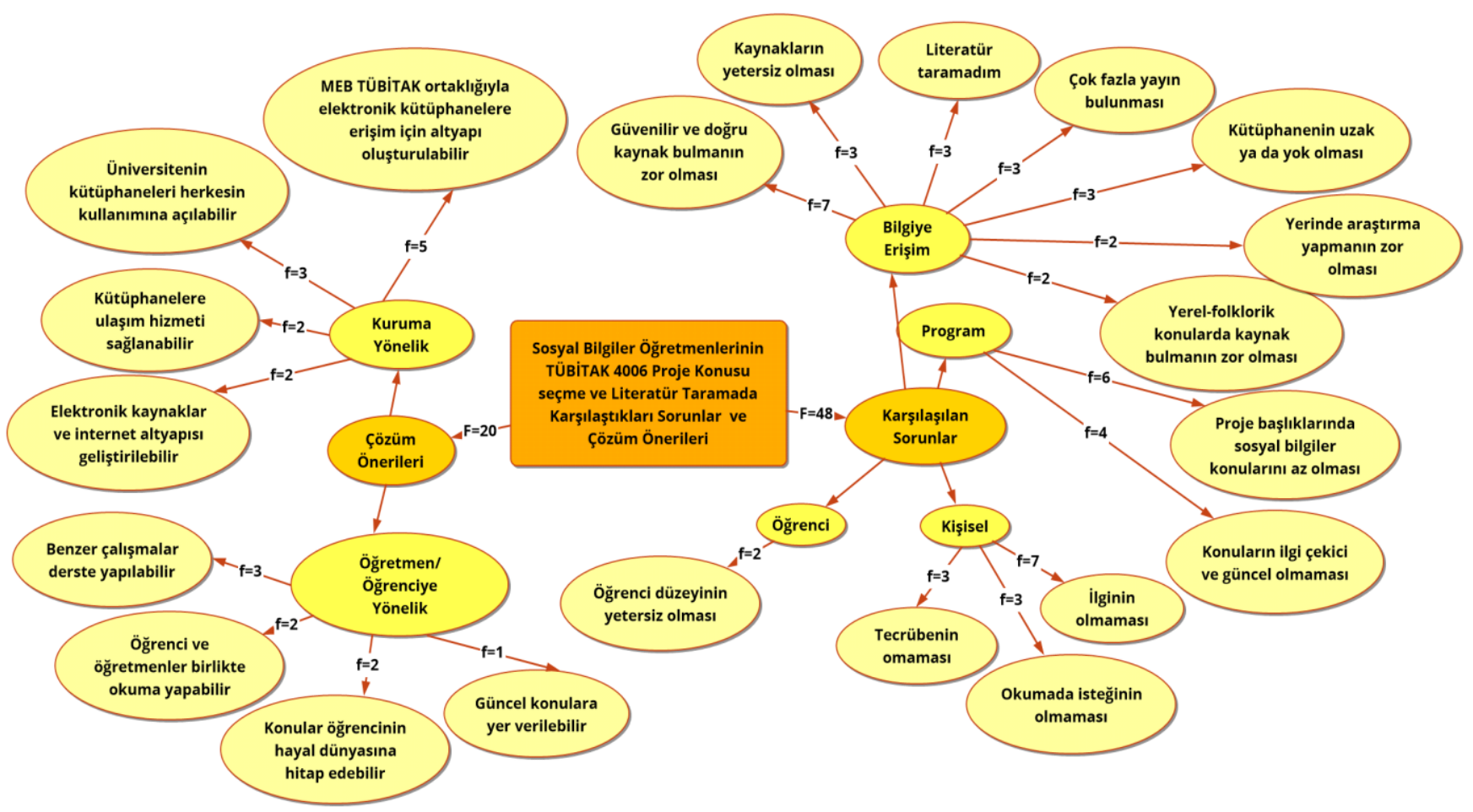

Şekil 1. Sosyal bilgiler öğretmenlerinin TÜBITAK 4006 proje konusu seçme ve literatür taramada karşılaştıkları sorunlar ve çözüm önerileri

Sosyal bilgiler öğretmenlerinin TÜBITAK 4006 proje konusu seçerken ve literatür taramada karşılaşılan sorunlar incelendiğinde öğretmenlerin bilgiye erişim, program yapısı ve kişisel kaynaklı olmak üzere üç temada on üç farklı kodda 48 görüş dile getirmiştir. Öğretmenler literatür tararken karşılaştıkları sorunlardan en çok doğru ve güvenilir kaynak bulmakta zorlandıklarını dile getirmiştir. $\mathrm{Bu}$ konu hakkında öğretmenlerden EÖ12 "Literatür taraması yaparken internette araştırma yaptığımızda güvenilir kaynak bulmak ve doğru bilgiye ulaşmakta zorlandık." ifadeleriyle görüşünü dile getirmiştir. Öğretmenlerden çalışma konusunu seçerken literatür taramadığını dile getiren çok sayıda kişi bulunmaktadır. Bu konuda öğretmenlerden KÖ1 "Literatür tarama ihtiyacı duymadım, konu zaten aklımdaydı..." ve KÖ13 "Proje konularımda literatür araştırmasına yönelik bir çalışma olmadı" ifadeleriyle görüşünü dile getirmiştir. Öğretmenler TÜBіTAK tarafından belirlenen konu başlıklarının sosyal bilgiler kapsamında ele alınacak konulara az yer verildiğini ve bu sebeple sorun yaşadıklarını da sıklıkla dile getirmiştir. Bu konuda öğretmenlerden EÖ5 "Daha çok Fen ve Teknoloji tasarım alanında projeler yapılabilirmiş gibi bir genel algı var. Bunu aşmak güç oluyor." KÖ7 
“TÜBITAK'ta konulara bakarsanız sosyal bilgiler alanında da daha az konunun yer aldığını görürsünüz bu nedenle konuya karar verirken sorun yaşadık" ifadeleriyle yaşadığı sorunu dile getirmiştir. Bireyden kaynaklı sorun olarak öğretmenler tarafından en çok dile getirilen görüş ilgi ve isteğin olmadığıdır. Bu konuda öğretmenlerden EÖ11 "Kişisel isteğimizle değil, kurumun talebi doğrultusunda katılım sağladık" ifadeleriyle konuyu mecburiyetten seçtiğini ve aslında ilgi ve istek duymadan konuyu belirlediklerini ifade etmiştir.

Sosyal bilgiler öğretmenlerinin TÜBITAK 4006 proje konusu seçme ve literatür taramada karşılaştığı sorunlara yönelik çözüm önerileri incelendiğinde iki ana tema ve sekiz farklı kodda olmak üzere 20 çözüm önerisi öğretmenler tarafından dile getirilmiştir. Bu hususta öğretmenlerin en çok dile getirdikleri, kurumlardan beklenen çözüm önerisi elektronik bilgi kaynaklarına ulaşım adına alt yapının oluşturulmasıdır. Öğretmenlerden KÖ7 “... görev yaptığım için literatür taraması yaparken kütüphaneye gidip araştırma yapma şansım olmadı. Ulaşabildiğim elektronik kaynaklara ulaşarak kaynaklarımı toparladım...ücretli bazı kaynaklara ulaşamadım, MEB bu konuyla ilgilenmeli" EÖ19 "kütüphanelere köy okullarının ulaşımının sağlanması ve sanal MEB ve üniversite kütüphanelerinin geliştirilmesi gerektiğini düşünüyorum" KÖ10 "Literatür taraması zor oluyor. TÜBITAK bu konuyla ilgili daha çözümleyici bir sistem oluşturmalı" ifadeleriyle görüşlerini dile getirmiştir. Benzer çalışmaların derslerde yapılması ve öğrencilerin ön planda tutulduğu konulara yer verilmesi öğretmenlerin çözüm önerisi olarak en çok dile getirdikleri görüş olmuştur. Bu konuda EÖ3 "Deneyim kazanmak için derslerde benzer çalışmaların daha sık yapılması iyi olabilir” ifadeleriyle görüşünü açıklamıştır.

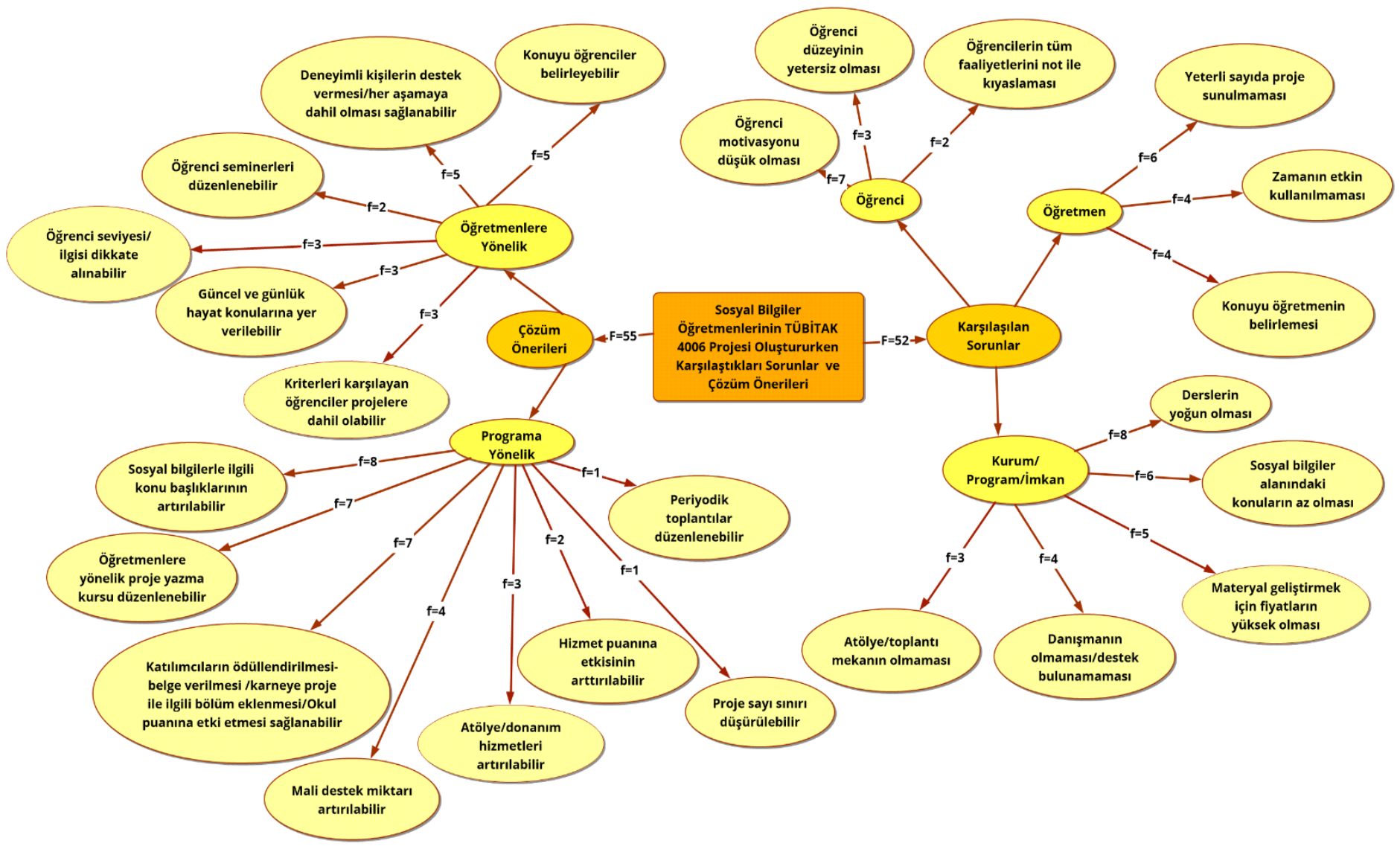

Şekil 2. Sosyal bilgiler öğretmenlerinin TÜBITAK 4006 projesi oluştururken karşılaştıkları sorunlar ve çözüm önerileri

Sosyal bilgiler öğretmenleri TÜBITAK 4006 projesi oluştururken karşılaştıkları sorunlar hakkında üç farklı ana tema ve 11 farklı kod olmak üzere 52 görüş dile getirmiştir. Bu hususta 
öğretmenler proje oluştururken, öğrenci motivasyonunun düşüklüğünü öğrenci kaynaklı sorun olarak çokça dile getirmiştir. EÖ5 "Öğrencilerin motivasyonu projelerin fikir aşamasından sonra düşüyor." ifadeleriyle görüşünü açıklamıştır. Öğretmen kaynaklı sorun olarak yeterli sayıda proje sunulmaması dile getirilirken, program kaynaklı sorun olarak en çok ders yoğunluğu ve sosyal bilgilerdeki konuların proje için elverişli olmayışı dile getirilmiştir. Bu kapsamda KÖ25 "Zümre arkadaşlarım konuya ilgisizdi bu nedenle az sayıda proje sunabildik" EÖ22 "Öğrencilerim ders yoğunluklarının fazla olması bu projelere olan ilgilerinin azalmasına yol açıyor" KÖ20 "Sosyal bilgilerde proje yapmaya elverişli konu $a z$ bu bizi zorlamıştı" ifadeleriyle görüşlerini açıklamıştır.

Sosyal bilgiler öğretmenleri TÜBITAK 4006 projesi oluştururken karşılaştıkları sorunlara yönelik çözüm önerileri incelendiğinde iki ana tema 15 farklı kod olmak üzere 55 görüş dile getirdiği belirlenmiştir. Öğretmenlere yönelik çözüm olarak konunun öğrencilerin belirlemesi ve deneyimli kişilerin sürece dahil edilmesi görüşü en çok dile getirilen çözüm önerileri olmuştur. KÖ1 "Proje oluştururken yol gösterici birinin olmaması beni zorladı. Yol gösterenlerin çoğalması bu soruna çözüm olabilir" EÖ8 "Öğrencilerin daha aktif olması gerektiğini düşünüyorum. Bence en önemli problem buydu. Çözüm önerisi olarak ta ögrencileri bu konuda uzmanları tarafından eğitim ve bilgilendirme verilmeli ve daha çok proje süreçlerine dahil edilmeli" ifadeleriyle çözüm önerisini dile getirmiştir. Öğretmenlerin programa yönelik en çok dile getirdikleri çözüm önerisi sosyal bilgiler alanında yapılabilecek konu başlıklarının artırıması ve proje yazma kurslarının düzenlenmesine yönelik görüşlerdir. Bu hususta EÖ11 "Konuyu belirlemek ve onu bir alanla eşleştirmek zor oluyor. Beni en çok zorlayan yazma süreci. Uygun kelimeyi bulma" ifadeleriyle görüşünü dile getirmiştir.

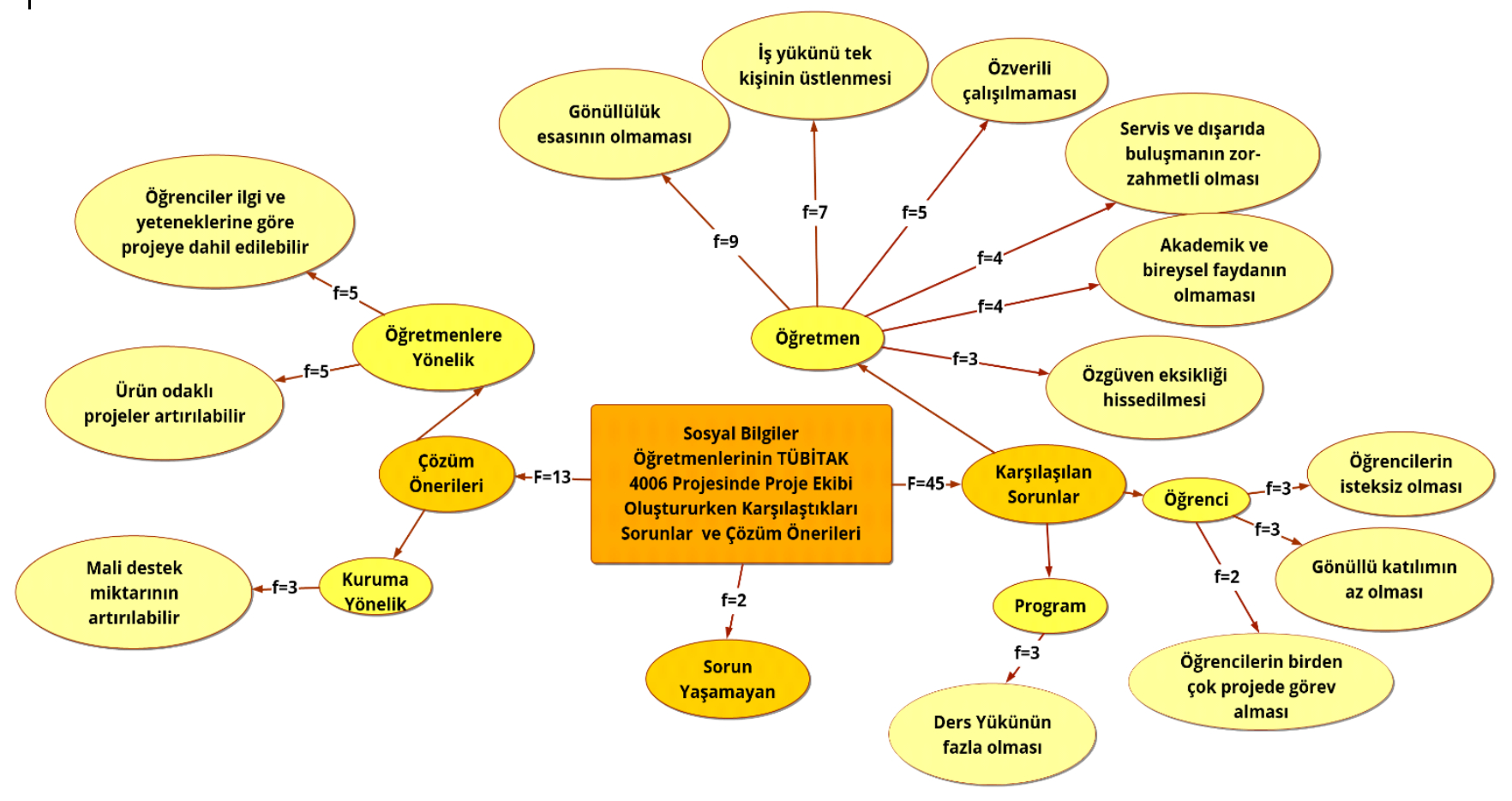

Şekil 3. Sosyal bilgiler öğretmenlerinin TÜBITAK 4006 projesinde proje ekibi oluştururken karşılaştıkları sorunlar ve çözüm önerileri

Sosyal bilgiler öğretmenleri TÜBITAK 4006 projesinde proje ekibi oluştururken karşılaştıkları sorunlar konusunda üç ana tema olmak üzere 11 farklı kodda 45 görüş dile getirmiştir. Öğretmenler, öğretmen kaynaklı sorun olarak ekip oluştururken gönüllülük esasının olmayışı ve iş yükünün bir kişide toplanması en çok karşılaştıkları sorun olarak dile getirmiştir. Bu hususta öğretmenlerden KÖ23 "Proje ekibini oluştururken karşılaştığımız en önemli sorun istekli öğretmen ve öğrencilerin olmaması 
olmuştur." ve KÖ15 "Bazen işin bir kişiye ait gibi görülmesi" ifadeleriyle görüşünü açıklamıştır. Öğretmenler, öğrenci kaynaklı sorun olarak öğrenci isteksizliği ve gönüllü katılımın azlığını dile getirmiştir. EÖ5 "Proje ekiplerini oluştururken 8. sını öğrencileri LGS odaklı hareket ettikleri için onları ikna etmek mümkün değil." KÖ7 "Özgüvenlerinin eksik olması nedeniyle katılmak istemediler." ifadeleriyle görüşünü açıklamıştır. Ders yükü fazla olduğu için öğretmen ve öğrencilerin proje ekibine dahil olmak istemeyişi de öğretmenler tarafından dile getirilen sorunlar arasındadır. Bu hususta KÖ1 "Ögrrencilerim ders yoğunluklarının fazla olması bu projelere olan ilgilerinin azalmasına yol açıyor" EÖ12 "Isteksizlik, ders yükünün fazla olması, zaman ayıramama, öğretmen arkadaşlarımızın katııımını engelleyen durumlardı, ekibi oluşturmak bu nedenle zor ve zaman almıştı" ifadeleriyle görüşünü dile getirmiştir.

Sosyal bilgiler öğretmenleri TÜBITAK 4006 projesinde proje ekibi oluştururken karşılaştıkları sorunlara yönelik çözüm önerisi olarak iki ana temada üç farklı kodla 13 görüş dile getirmiştir. Öğretmenlerin öğrencilerin yeteneklerine göre projeye dahil edilmesi ve ürün odaklı projelere ağırık verilebileceği çözüm önerisi olarak dile getirilen görüşlerdir. EÖ26 "Öğrencilerin yeteneklerini keşfederek okulda farklı bir ortam oluşturularak katılım artırılabilir." ve KÖ9 "Daha çok yerel, folklorik özellikte proje konular öğrencilerin dikkatini çekmeyebiliyor, ellerinde somut bir ürün görmeleri onları teşvik edecektir" EÖ6 "Taleplerin artması somut fayda ile orantılıdır diye düşünüyorum. Ürün ürettiğini gören çocuklar daha istekli olabilir" ifadeleriyle görüşünü açıklamıştır. Öğretmenler ayrıca, kuruma yönelik olarak mali desteğin artırımasının ekip oluşturma adına teşvik edeceği ve katılımın artabileceğini de dile getirerek çözüm öneri sunmuştur. Bu konuda EÖ21 "Proje destek miktarı arttırılmalı. Öğretmenlere hizmet puanı, öğrencilere okul puanı verilmeli ancak bu şartlarda katılım artırılabilir" ifadeleriyle görüşünü dile getirmiştir.
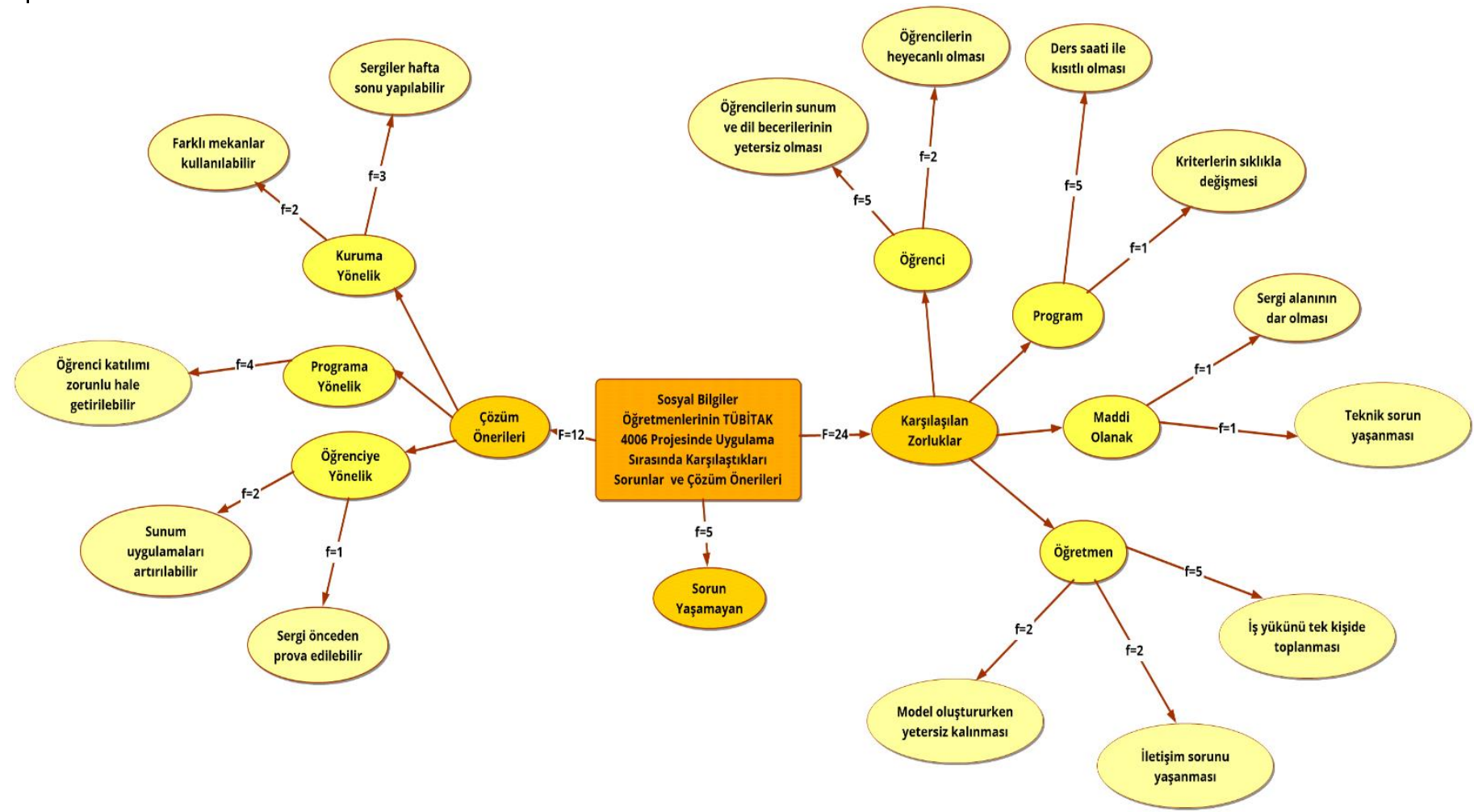

Şekil 4. Sosyal bilgiler öğretmenlerinin TÜBITAK 4006 projesinde uygulama sırasında karşılaştıkları sorunlar ve çözüm önerileri

Sosyal bilgiler öğretmenleri TÜBITAK 4006 projesinde uygulama sırasında yaşadıkları sorunlar hakkında 4 ana tema dokuz farklı kod olmak üzere 29 görüş dile getirmiştir. Bu konuda öğrenci kaynaklı sorun olarak en çok sunum, dil ve ifade becerileri üzerine görüş dile getirilmiştir. 
Öğretmenlerden EÖ5 "Öğrencilerin Türkçeyi kullanma becerilerine sorun olmaktadır." KÖ7 "Projelerin sunumu noktasında ki yetersizlikler planlanan amacın daha çok öğrenciye ulaşmasını engelliyor..." Ö21 "Öğrencilerin aşırı heyecanlı olması sunum sırasında sorunlara neden oldu." ifadeleriyle kendini ifade etmiştir. Program kaynaklı sorun olarak projenin ders saati ile sınırlı olması dile getirilirken EÖ22 "Bu aşamada zaman dışında bir sorun yaşamadım. Öğretmenlere projeler için egzersiz çalışmaları veriliyor ancak bu pandemi döneminde fiili bir çalışma olmadığı için bunu kendimizden fedakarlık ederek yapıyoruz bu konuda bir düzenleme gerekiyor. Dersler yoğun ve projenin ders saatleri içinde yapılıyor olması bir sorundu" ifadeleriyle görüşünü açıklamıştır.

Sosyal bilgiler öğretmenleri TÜBITAK 4006 projesinde uygulama sırasında yaşadıkları sorunlara ilişkin dört ana tema 6 farklı olmak üzere 25 çözüm önerisi dile getirmiştir. Öğretmenler uygulama sırasında karşılaştıkları sorunlara karşı çoğunlukla önerisinin olmadığını dile getirmesinin yanı sıra farklı görüşler de ifade etmiştir. Bu konuda öğretmenler, sergilerin derslerle çakışmasından dolayı hafta sonu yapılabileceği çözümünü sıklıkla dile getirmişlerdir. EÖ3 "Ders saatlerini takip eden günlerde yorgunluk, zaman ayıramama, ulaşım. Hafta sonu yapılabilir, okul idaresi gerekli tedbirleri almakta yardımcı olabilir" ifadeleriyle görüşünü dile getirmiştir. Programa yönelik olarak öğrencilerin zorunlu olarak sürece dahil edilebileceği sıklıkla dile getirilmiştir. Öğretmenlerden EÖ8 “En önemli sorun işlerin herkes tarafından aynı titizlikle ve zamanında yapılmaması. Öğrenci gönüllü olarak katılmıyorsa zorunlu tutulup sürece dahil edilebilir." ifadeleriyle bu konudaki görüşünü dile getirmiştir.

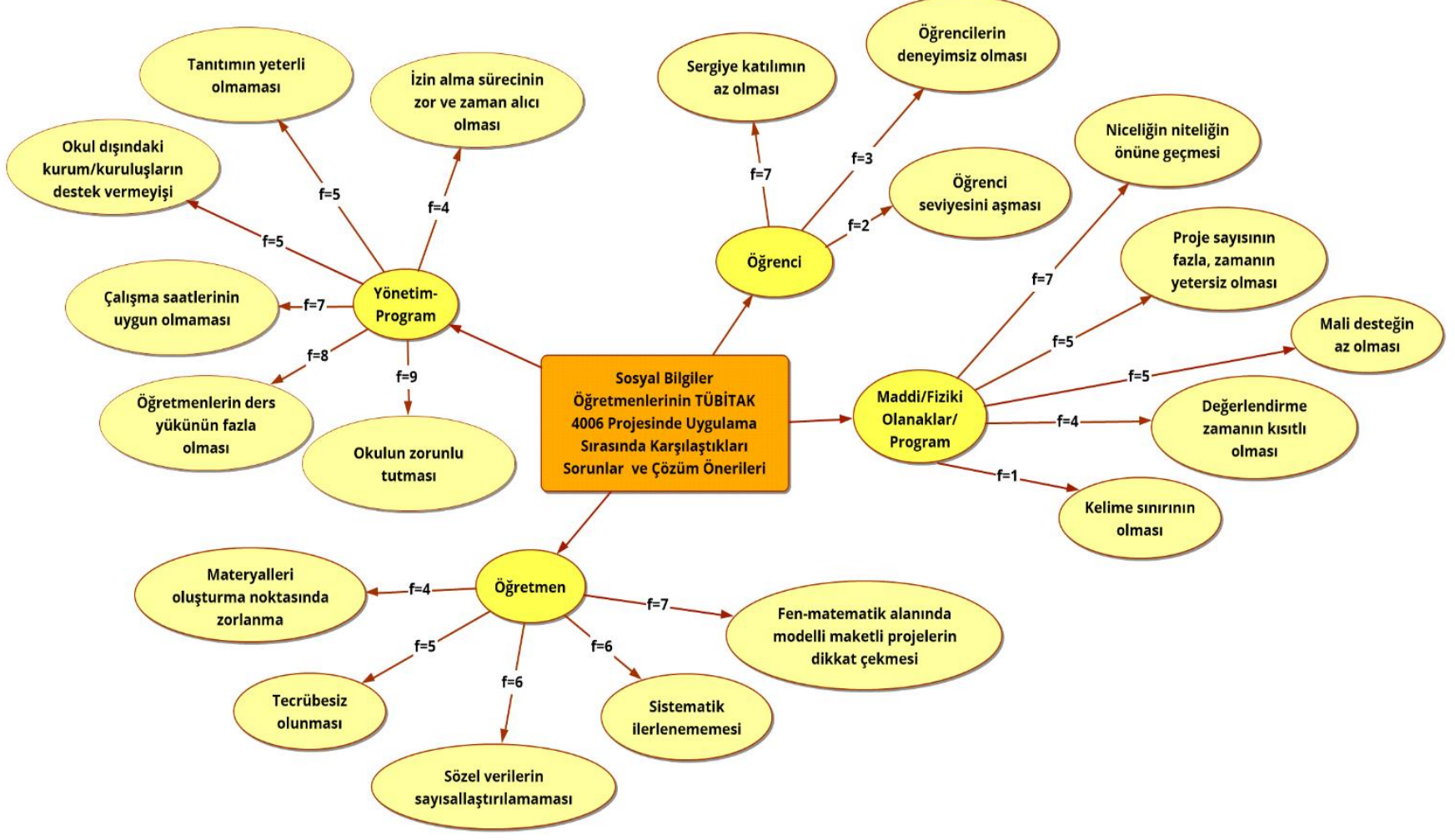

Şekil 5. Sosyal bilgiler öğretmenlerinin TÜBITAK 4006 projesinin değerlendirme sürecinde karşılaştıkları sorunlar ve çözüm önerileri

Sosyal bilgiler öğretmenleri TÜBITAK 4006 projesinin değerlendirme sürecinde karşılaştıkları sorunlar konusunda 4 ana tema olmak üzere 19 farklı kodda 100 görüş dile getirmiştir. Öğretmenlerin öğrenci kaynaklı sorun olarak en çok dile getirdikleri görüşün sergiye katılımın az olduğu yönündedir. Konu hakkında EÖ30 "Sergi alanının yetersiz olması en önemli sorunlardan bir tanesi olmuştur. Okulların küçük salonlarında sergilerin yapılması daha az sayıda insana ulaşmasına yol açıyor." EÖ8 
"Sergilere katılımı yeterli buluyorum. Ancak projelerin yerelde kalmayıp ulaşılan kişi sayısının artırılması gerektiğini düşünüyorum" ifadeleriyle görüşünü dile getirmiştir. Öğretmenlerin program kaynaklı sorun olarak en çok dile getirdikleri görüş ise niceliğin niteliğin önüne geçtiği yönündedir. Bu anlamda KÖ15 "Projede rehber öğretmendim. Bazı okullar projeye sırf para almak için katılıyor ve projeleri öğretmenlerin kendileri yapıyor. Okulların belirli sayıda proje sunması gerekiyor bu da niceliği niteliğin önüne alıyor" ifadeleriyle görüşünü açıklamıştır. Bu konuda öğretmen kaynaklı sorun olarak en çok dile getirilen görüş modelli maketli projelerin daha çok dikkat çekmesi ve sosyal bilgiler alanında bu materyallere daha az yer verilişidir. KÖ13 "Değerlendirme sürecinde daha çok sayısal alan ve maket tarzı projeler popüler oldu. Fikir tarzı bir proje pek rağbet görmedi hiç" ifadeleriyle görüşlerini açıklamıştır. Yönetim ve program kaynaklı sorun olarak en çok dile getirilen görüş okulun zorunlu tutması ve ders yükünün fazla olduğu yönündedir. Bu konuda EÖ29 “ ...katılım okul bazında zorunluydu bu zaruret isteksizlik oluşturdu" ifadeleriyle görüşünü dile getirirken KÖ4 "Danışman ögretmenlerin katılımı az oluyor maalesef. Yani bazılarına çok zor geliyor raporlaştırma ve sürece katılma. Onlar da haklı olabilir çünkü dersleri çok yoğun" ifadelerini kullanmıştır.

\section{İkinci Alt Probleme ilişskin Bulgular}

Sosyal bilgiler öğretmenlerinin TÜBITAK 4006 Projelerine katılma amaçları ve bu amaçlara ulaşma durumlarına ilişkin görüşleri şekillerle sunulmuştur. Şekillere ilişkin açıklama ve görüşlerden doğrudan yapılan alıntılar ilgili şeklin altında sunulmuştur.

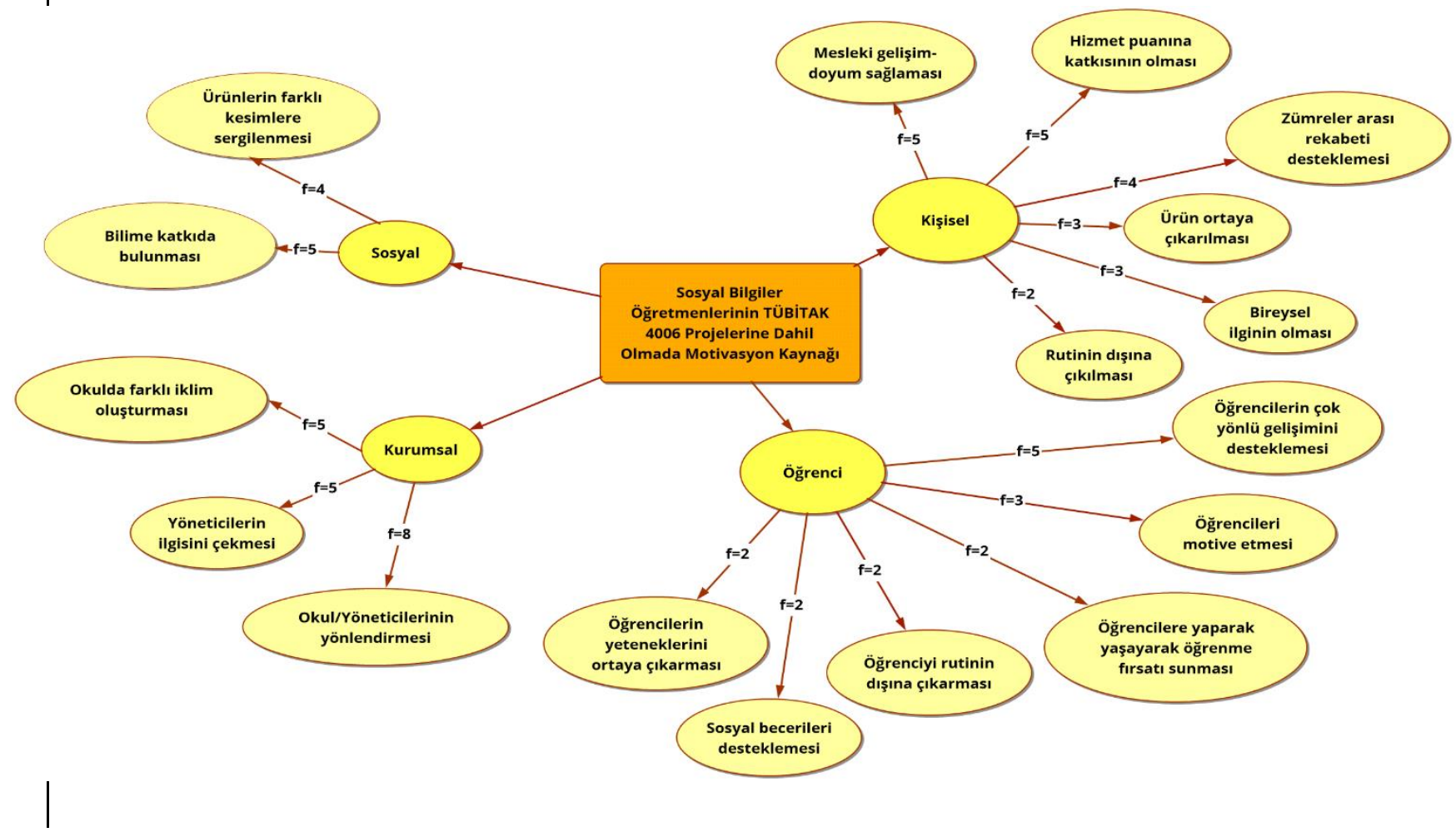

Şekil 6. Sosyal bilgiler öğretmenlerinin TÜBITAK 4006 projelerine dahil olmada motivasyon kaynağı

Sosyal bilgiler öğretmenleri TÜBITAK 4006 projelerine katılmalarında motivasyon kaynağı olarak dört tema 18 farklı kod ile 63 görüş bildirmiştir. Motivasyon kaynağının kişisel olarak meslekigelişim ve doyum sağlamak olduğu görüşünü dile getiren öğretmenlerden EÖ5 "Kişisel olarak sürekli öğrenmeye, araştırmaya ve sorunlara çözüm bulmaya dönük bir yaklaşıma sahip olmak gibi bir yönelime sahip olmak en önemli kazanımım oldu. Farklı alanlarda, farklı konularda bilgi ve 
tecrübelerim oldu. Farkı insanlarla, alanında uzman kişilerle çalışma fırsatı buldum." EÖ22 "Öğrenme ögrretme ve kendimi geliştirmede faydalarını görüyorum" ifadeleriyle görüşünü açıklamıştır. Öğretmenler bir diğer görüş olarak öğrencilerin çok yönlü gelişimini sağlamak ve yaşayarak öğrenme fırsatı sunduğu için projelere dahil oldukları en çok dile getirilen görüşlerdir. Bu kapsamda öğretmenlerden KÖ9 "Bilişsel ve psikomotor öğrenmeler açısından zengin fırsatlar sunması, zengin ögrenme fırsatı sağlıyor, biz derslerde bunu yapamayabiliyoruz yani her öğrenme alanına hitap edemeyebiliyoruz." ifadelerini kullanırken EÖ6 "Öğrencilerimle yaparak yaşayarak öğrenmek istemem. Öğrencilerin de bunu yapacak olması projeler konusunda yüreklenmek ve yüreklendirmek." ifadeleriyle görüşünü dile getirmiştir. Kurumun yönlendirmesiyle projelere dahil olduğunu dile getiren öğretmenlerden EÖ3 "Katılmayı kendim istemedim kurumum zorunlu tuttuğu için katılmıştık" ifadeleriyle görüşünü dile getirmiştir.

\section{Üçüncü Alt Probleme îlişkin Bulgular}

Sosyal bilgiler öğretmenlerinin 4006 TÜBITAK projelerinin kendilerine, topluma ve öğrencilere katkılarına ilişkin görüşleri şekillerle sunulmuştur. Kod ve temalara ilişkin açıklama ve katıımcıların ifadelerinden doğrudan alınan cümlelere ilgili şeklin altında sunulmuştur.

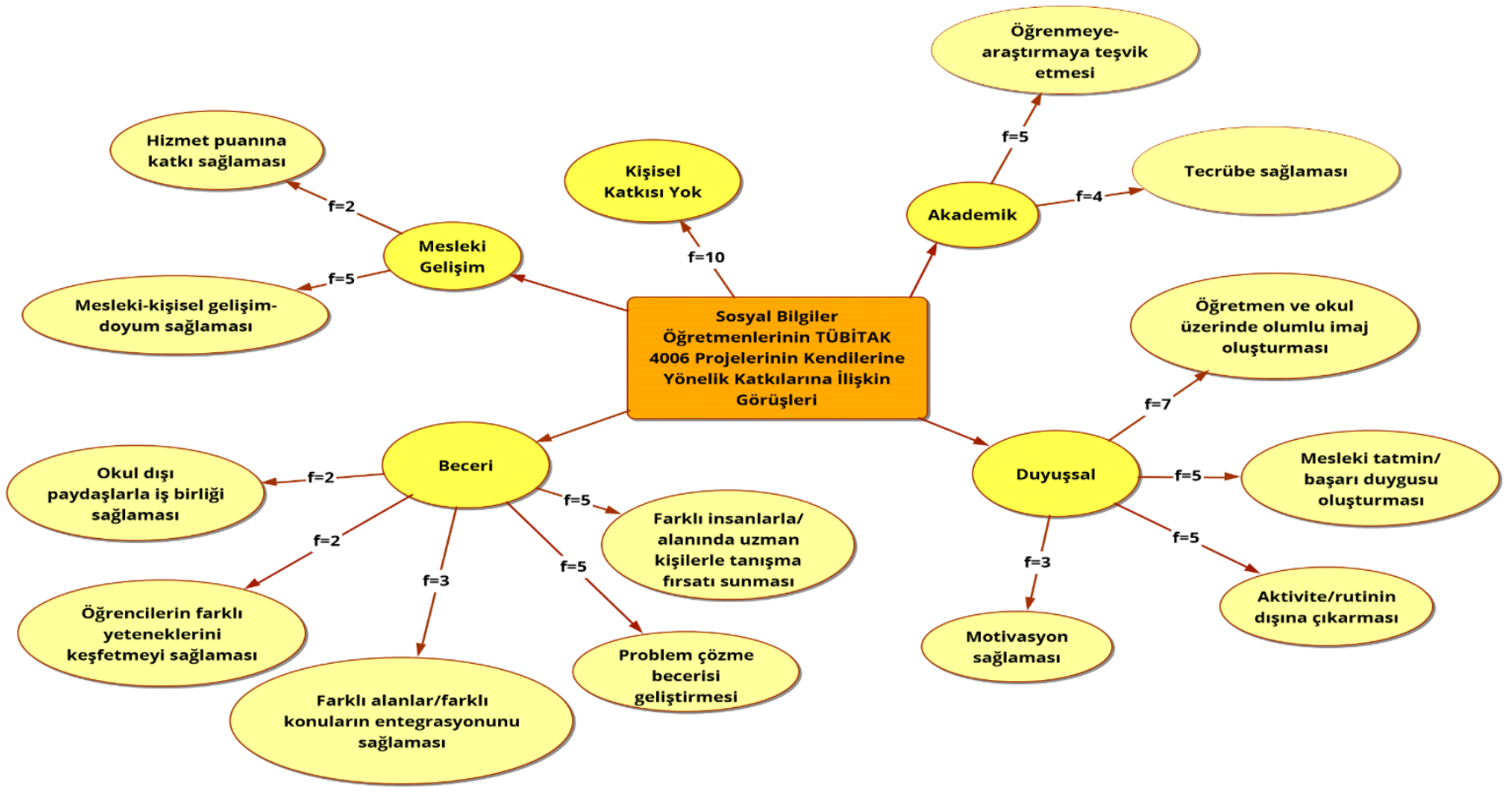

Şekil 7. Sosyal bilgiler öğretmenlerinin TÜBITAK 4006 projelerinin kendilerine yönelik katkılarına ilişkin görüşleri

Sosyal Bilgiler Öğretmenleri TÜBITAK 4006 Projelerinin Kendilerine Yönelik Katkılarına İlişkin dört temada olmak üzere 14 farklı kodda 72 görüş dile getirmiştir. Öğretmenler akademik katkı olarak projelerin öğrenme ve araştırmaya teşvik sağladığını sıklıkla dile getirmiştir. Bu hususta öğretmenlerden EÖ17 "Literatür taraması yaparken internette araştırma yaptığımızda güvenilir kaynak bulmak ve doğru bilgiye ulaşmakta zorlandık. Yazılı kaynak taraması sırasında konuyla ilgili yazılı- basılı kaynak bulmakta zorlandık ama bu bizi araştırma yapmaya daha da teşvik etti" ifadeleriyle görüşlerini dile getirmiştir. Duyuşsal katkı olarak çevreden alınan olumlu görüşlerin etkili olduğu dile getirilirken öğretmelerden EÖ22 "Aktif olmak, yeni kavramlar öğrenmek, başarma duygusu, çevrenin olumlu dönüşleri kesinlikle muazzam bi mutluluk sağlıyor" ifadeleriyle görüşünü 
açıklamıştır. Proje sürecinin işbirliği ve problem çözme becerilerini geliştirdiği öğretmenler tarafından sıklıkla dile getirilen görüşler arasındadır. Bu hususta KÖ18 "Bugüne kadar öğrenmiş olduğumuz konuların farklı yönlerine dikkat çekerek bilinç oluşturmaya çalıştık, olayların çok boyutluluğunu görmüş olduk. Derste öğrendiğimiz problem çözme basamaklarını uygulamış olduk bu da çocuklarda problem çözme becerisini ve birlikte iş çıkarma becerisi geliştirmiştir zannımca" ifadeleriyle görüşünü dile getirmiştir. Proje sürecinin kişisel katkısının olmadığı da öğretmenler tarafından sıklıkla dile getirilen görüşlerdendir. Bu konuda öğretmenlerden KÖ2 "Kişisel bir katkısı yok maalesef, dediler katıldık" ifadeleriyle görüşünü dile getirmiştir. Bu görüşün yanı sıra öğretmenlerden proje sürecinin kişisel gelişim sağladığını ifade eden öğretmenlerden EÖ11 "Bu konuda da bir tecrübe edinmiş olduk. Mesleki olarak derste öğrendiğiniz bilgileri uygulama fırsatı bulduk. Kişisel olarak başarma ve hedefe ulaşma duygusu tabi ki en büyük kazanımımız oldu" ve KÖ15 "Öğrencilerimle birlikte çalışmak, ortaya bir ürün koymak çok zevkli. Motivasyonumu artırıyor. Fuar aşamasında daha fazla insan tanıyoruz. Mesleki açıdan tatmin edici bir sonuç alabiliyorum" sözleriyle kendini ifade etmiştir.

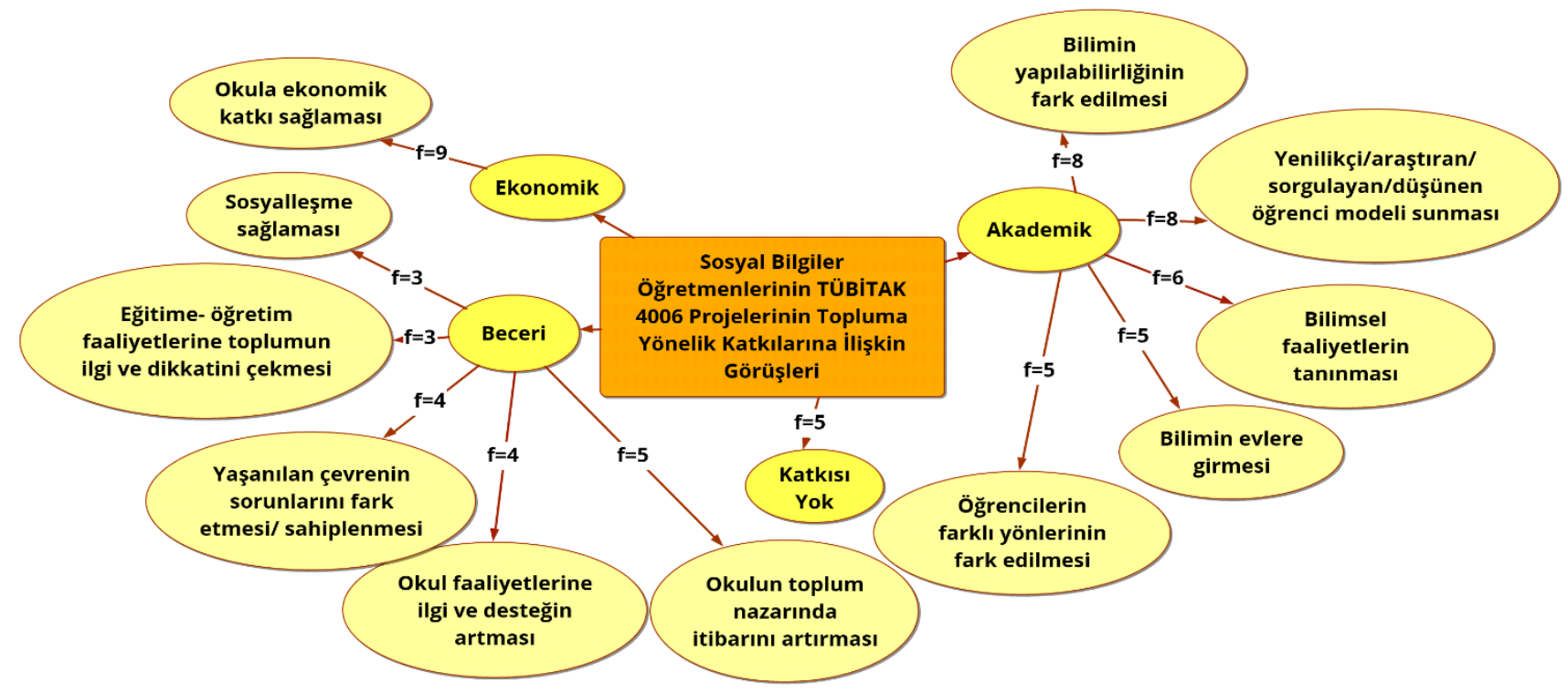

Şekil 8. Sosyal bilgiler öğretmenlerinin TÜBITAK 4006 projelerinin topluma yönelik katkılarına ilişkin görüşleri

Sosyal Bilgiler Öğretmenleri TÜBITAK 4006 Projelerinin Topluma Yönelik Katkılarına İlişkin üç temada 12 farklı kodda olmak üzere 65 görüş dile getirmiştir. Öğretmenler proje sürecinin topluma yönelik akademik katkı olarak en çok bilimin yapılabilirliğinin fark edilmesi ve çok yönlü öğrenci özelliği sunabileceği görüşünü dile getirmiştir. Bu konuda öğretmenlerden KÖ7 "Bilimin yapılabilirliğinin fark edilmesi için faydalı diye düşünüyorum" ifadeleriyle görüşünü dile getirirken KÖ24 "Daha yenilikçi araştıran sorgulayan düşünen bir öğrenci grubunun oluşmasına destek oluyor" EÖ5 "Bilim kısa bir sürede olsa evlere giriyor." ifadeleriyle görüşlerini açıklamıştır. Öğretmenler projelerin okulların itibarını artırdığını dile getirmesinin yanı sıra toplumsal katkının olmadığını da sıklıkla ifade etmiştir. Bu hususta öğretmenlerden EÖ29 "Görsel olarak sergiler okulun imajı açısından faydalı oldu" ve KÖ2 "Toplumsal bir katkısı olduğunu düşünmüyorum" ifadeleriyle görüşünü dile getirmiştir. Öğretmenler tarafından en çok dile getirilen görüş projelerin okullara ekonomik katkı sağladığı yönündedir. Bu konuda öğretmenlerden EÖ30 "Toplumsal açıdan faydalı ancak birçok kimse bu fuarların neden niçin yapıldığının farkında değil bu yüzden okullara ekonomik katkı sağlıyor ki projeler hep bu yüzden yapılıyor" ifadeleriyle görüşünü açıklarken EÖ3 "Birçok öğretmen bu projelere bilim için değil okul idaresi ile ters düşmemek için katılıyor. Öğretmenlerin daha başarılı işler çıkartması için okul idaresi değil öğretmenler desteklenmeli, okul da alacağı paraya bakıyor" ifadelerini kullanmıştır. 
Sosyal Bilgiler Öğretmenleri TÜBITAK 4006 Projelerinin Öğrencilere Yönelik Katkılarına İlişkin üç temada 17 farkı kodda 68 görüş dile getirmiştir. Projelerin öğrencilere akademik katkısı olarak işbirliği ve otokontrol becerisi geliştirdiği öğretmenler tarafından sıklıkla dile getirilmiştir. Bu konuda öğretmenlerden EÖ14 "Öğrenci çalışırken bilimsel süreçleri ve etik kuralları fark ediyor. Çalışmasını sunarken iletişim ve özgüven, otokontrol becerileri gelişiyor" ifadeleriyle görüşünü açıklarken KÖ1 “...öğrencilere grup çalışması ile özgüven geliştirmesi noktasında da katkıları olmuştur" ifadelerini kullanmıştır. Projelerin öğrencilerde duyuşsal sorumluluk duygusu geliştirdiği, yeniliklere açık- farklı bakış açısı kazandırdığı, derse ilgiyi artırdığı yönünde görüşler öğretmenler tarafından sıklıkla dile getirilmiştir. EÖ5 "Kendini ifade etme, farklı bakış açısı kazanma, çevremizdeki sorunları görme ve onlara çözüm üretme becerisi kazandıklarını düşünüyorum. Bence en önemli katkı bizde bir şeyler yapabiliyoruz duygusu ve öz benlik algısının yükselmesini olumlu etkilemesidir" ifadeleriyle görüşünü dile getirmiştir. Öğretmenlerden projelerin öğrencilere herhangi bir katkııının olmadığını dile getirenler de yer almıştır. Bu hususta öğretmenlerden EÖ3 “Katkı sağladığını düşünmüyorum" ifadelerine yer vermiştir.

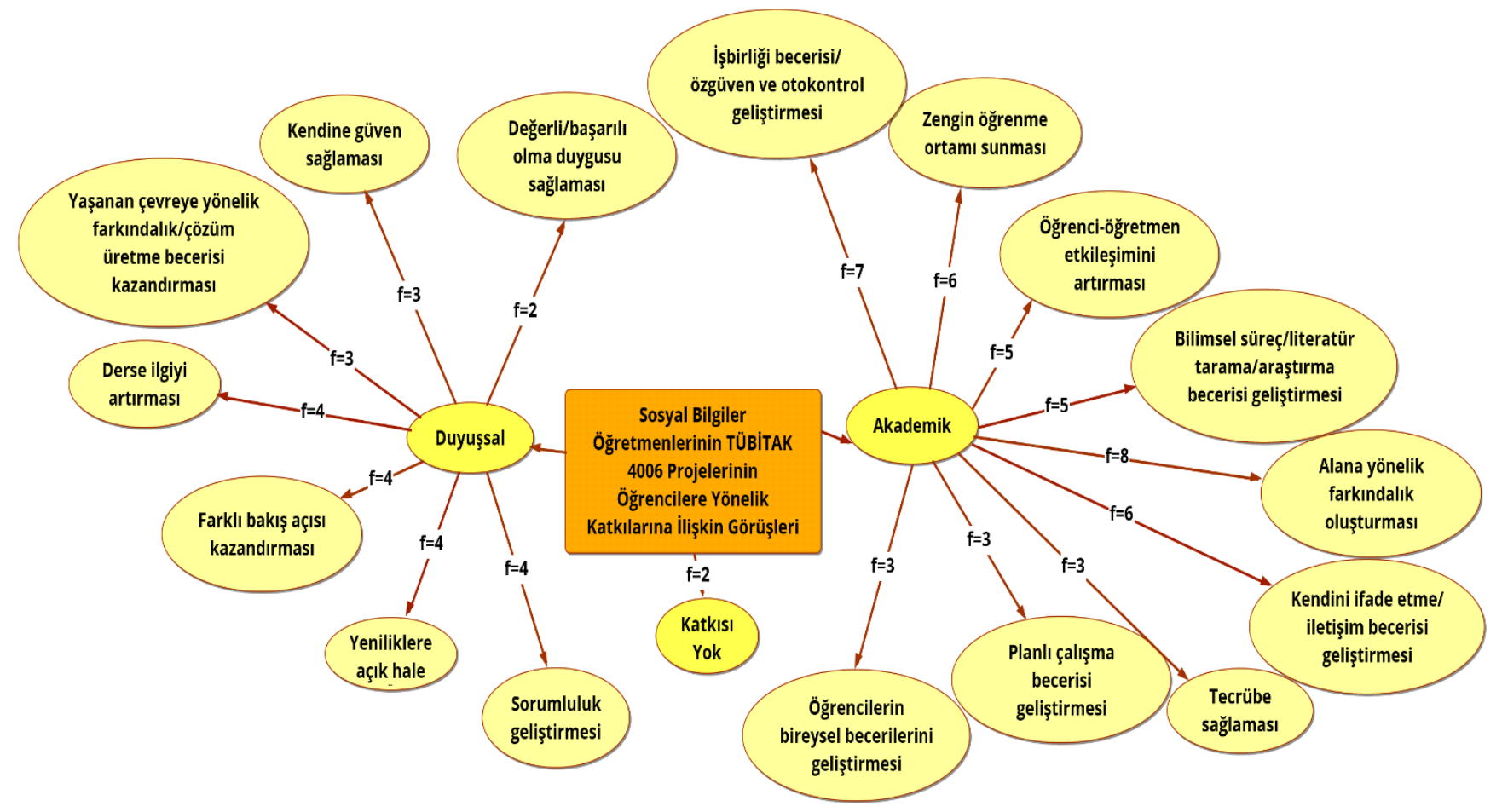

Şekil 9. Sosyal bilgiler öğretmenlerinin TÜBITAK 4006 projelerinin öğrencilere yönelik katkılarına ilişkin görüşleri

\section{Tartışma, Sonuç ve Öneriler}

Bu çalışmada sosyal bilgiler öğretmenlerinin TÜBITAK 4006 proje süreçlerine dair görüşlerini ve bu süreçte karşılaştıkları sorunları ve bu sorunlara önerdikleri çözümleri ortaya koymak amaçlanmıştır. Bu bağlamda çalışmadan elde edilen sonuçlara göre sosyal bilgiler öğretmenlerinin konu seçme ve literatür tarama konusunda yetersiz kaldığı ifade edilebilir. En sık tekrar edilen "güvenilir ve doğru kaynak bulmanın zorluğu, kaynak yetersizliği ve çok yayın bulunması kodları" öğretmenlerin literatür tarama adına sorun yaşadıkları ve bu alanda yeterli donanıma sahip 
olmadıkları fikrini ortaya çıkarmaktadır. Bu sonucun aynı doğrultuda farklı araştırma gruplarıyla yürütülen çalışmalardaki sonuç ile paralellik gösterdiği söylenebilir. Nitekim Oğuz-Ünver vd. (2015); Özel ve Akyol (2016), Tortop (2013) tarafından yapılan çalışmalarda da öğretmenlerin literatür taramada eksikliklerinin bulunduğu dile getirilmiştir. Bu sonuçtan farklı olarak Sözer (2017) yaptığı çalışmada öğretmenlerin literatür tarama bilgisinin iyi olduğundan bilimsel makale ve tezlere erişim konusunda yeterli bilgi düzeyine sahip olduğuna değinmiştir. Bu farklılık çalışma grubuna dahil olan öğretmenlerin mesleki kıdem ve mezun olunan dönemlerinin farklı olmasıyla ilgili olabilir. Nispeten daha yakın dönemde mezun olan öğretmenlerin bilimsel araştırma ve proje dersleri aldıkları bu nedenle literatür tarama adına sorun yaşamaması muhtemeldir.

TÜBITAK 4006 projelerinin öğrenciler tarafından oluşturulması öğretmenlerin ise bu konuda rehber konumunda olması beklendiği bilinmektedir. Ancak yapılan çalışma sonucu proje konularının çoğunlukla öğretmenler tarafından belirlendiği söylenebilir. Nitekim çalışmanın ilerleyen kısımlarında bu durum öğretmenler tarafından da dile getirilmiştir. Konunun öğretmenler tarafından belirlenmiş olması konu seçiminde öğretmenlerin yaşadığı sorunları da beraberinde getirdiği düşünülmektedir. Bu anlamda öğretmenler konuyu kendi belirlemiş olmalarının sorunlarına değinerek görüşlerini dile getirmiştir. Konu seçiminde yaşanan sorunlar incelendiğinde bazı başlıkların literatürle paralel olduğu görülmektedir. Çalışmadan elde edilen sonuçlara göre öğretmenlerin projelere dahil olmaları nispeten yenidir. Öğretmenler tarafından sıklıkla dile getirilen tecrübe unsuru proje konusu belirlemede de karşımıza çıkmaktadır. Öğretmenlerin proje konusu belirlemeye yönelik tecrübelerinin olmayışı Tortop (2013) tarafından yapılan çalışmada bir sorun olarak dile getirilmiştir. Buna paralel olarak yapılan birçok çalışmada tecrübe eksikliğinin proje sürecinde öğretmen ve öğrencilerin farklı sorunlarla karşılaşmasına neden olduğu vurgulanmıştır (Arı, 2010; Aydın, Bacanak ve Çepni, 2013; Aydın ve Çepni, 2011; Avcı vd., 2016; Baki ve Bütüner, 2009; Çetin ve Şengezer, 2013; Durmaz vd., 2017; Fallik vd., 2008; Güven, 2013; Oğuz-Ünver vd., 2015; Özel ve Akyol, 2016; ÖztunaKaplan ve Diker-Coşkun, 2012; Sözer, 2017; Tortop, 2014). Ayrıca öğretmenlerin gönüllü olarak değil üst makamların yönlendirmesi nedeniyle projeye dahil olmaları onların konu seçiminde sorun yaşamalarına neden olmuş olabilir. Oğuz Ünver vd., (2015) yaptığı çalışmada öğretmenlerin konu belirlerken herhangi bir soruna odaklanmak ve nasıl çözüleceğinden hareket etmek yerine bilgi odaklı hareket edip konu seçmelerinin proje üretimine engel olduğunu ifade etmektedir. Bu bağlamda öğretmenlerin konu belirlerken var olan bir sorun üzerinden hareket etmek yerine yapılan ve yapılabilecek çalışmalardan hareket etmeleri konu belirleme adına sorun oluşturduğu düşünülebilir. Yine aynı çalışmada öğretmenlerin proje hazırlama konusunda kendilerini yetersiz hissettiklerinden bahsedilmiştir. Yaptığımız çalışmada ise öğrenci düzeyinin yetersizliği vurgusu yapılarak bunun konu belirleme adına sorun oluşturduğundan bahsedilmiştir. Tortop (2013) tarafından yapılan çalışmada da öğretmenlerin öğrencileri proje hazırlamaya teşvik etme ve yönlendirme adına sorun yaşadığından bahsetmiştir. Bu çalışmada da öğretmenlerin öğrencileri yönlendirme ve teşvikte yetersiz kaldığı için öğrencilerin konu belirlemede sorun oluşturduğu ifade edilebilir. Yine sosyal bilgiler öğretmenlerinin TÜBITAK sitesinde Bilim Fuarı Tematik Alt Proje Alanları arasında sayılan konu başlıklarını sosyal bilgiler açısından yeterli görmediği söylenebilir. Bu durum ise öğretmenlerin konu belirlemelerinde sorun yaşamalarında neden teşkil edebilir. TÜBiTAK'ın tablo halinde paylaştığı konuların dağılımları incelendiğinde konu başlılarının fen ve teknoloji alanında yoğunluk kazandığı ifade edilebilir (TÜBITAK Web2). Konu alanının dar olması öğretmenlerin görüşü üzerinde etkili olduğu düşünülmektedir.

Sosyal bilgiler öğretmenlerinin TÜBITAK 4006 projesi oluşturulurken karşılaştıkları sorunlar incelendiğinde çoğunlukla öğretmen ve program kaynaklı sorunların dile getirildiği görülmektedir. Bu durumun sebebi projelerin öğretmenler tarafından önerilmesi nedeniyle sorunların öğretmenler açısından değerlendirilmesi ya da görüşmenin öğretmen bakış açısıyla gerçekleştirilmesinden kaynaklı olabilir. Öğrenci kaynaklı en çok dile getirilen görüşün öğrenci motivasyon düşüklüğü olduğu görülmektedir. Sosyal Bilgiler Öğretmenlerinin TÜBITAK 4006 Projesi oluşturulurken öğrenci motivasyonunu yeterli görmediği ifade edilebilir. Öğrenci motivasyon düşüklüğü öğrencilerin 
yapılması planlanan proje ve süreçleri hakkında yeterli bilgiye sahip olmadıklarından kaynaklandığı düşünülmektedir. Bu aşamada öğretmenlerin rehberlik konusunda yetersiz kaldığı ifade edilebilir. Bu sonucun literatürle paralellik gösterdiği söylenebilir. Nitekim Oğuz-Ünver vd. (2015), Tortop (20132014) yaptı̆̆ı çalışmada öğretmen rehberliğinde yaşanan yetersizlik neticesinde öğrencilerin motivasyonunda sorun yaşadıklarını ifade etmiştir. Proje süreçlerinin ve katkılarının öğretmenler tarafından tam anlamıyla anlaşılmamasından öğrencilerin de konu hakkında bilgi sahibi olmamasına sebep olmuş bu ise öğrencilerde motivasyon düşüklüğüne neden olmuş olabilir. Nitekim öğretmenlerin çözüm önerilerinin yine meslektaşlarına yönelik olması bu fikri güçlendirmektedir. Literatürdeki veriler de bu görüşü destekler niteliktedir. Sözer (2017) yaptığı çalışmada öğrenci motivasyonunu sağlamak için yapılan projelerin ders notlarına ek puan getirmesi, projenin kendilerine katkılarının ne olacağı, öğretmenlerin proje hazırlama seminerlerine katıldığından bahsetmektedir. Çalışmadan elde edilen sonuçlara göre öğretmenlerin proje süreçleri hakkında yeterli bilgi ve deneyime sahip olmadıkları ve bu süreçte rehberliğe ihtiyaç duyduğu söylenebilir. Bu sonucun literatürle paralellik gösterdiği söylenebilir. Bulunuz (2011) da yaptığı çalışmada öğretmenlerin bilgi-deneyim eksikliklerine dikkat çekmektedir. Yine Tortop (2013) yaptığı çalışmada öğretmenlerin deneyim eksikliklerinden kaynaklı sorunları dile getirmiş ve rehberlik konusunda da yeterli olamadıklarını sonucunu paylaşmıştır. Öğretmenlerin proje oluştururken karşılaştıkları sorunlara yönelik önerilen çözümler sorunların çözümünde etkili bir yol sunabilir. Deneyimli kişilerin projeye destek vermesi ve proje yazmaya yönelik seminer verilmesi görüşü sıklıkla dile getirilen görüşlerin farklı çalışmalarda uygulandığı ve projeler adına avantaj sağladığı literatürde yer almaktadır. Oğuz-Ünver vd. (2015) öğretmenlerin kendilerine rehberlik edecek kişilere ihtiyaç duyduklarını paylaşırken, Sözer (2017) çalışmasında danışman olmasalar da deneyimli öğretmenlerin proje çalışmalarına destek vermelerinin olumlu taraflarına değinmiştir.

Sosyal Bilgiler Öğretmenlerinin TÜBITAK 4006 projesinde proje ekibi oluştururken karşılaştıkları sorunların çoğunlukla öğretmen kaynaklı olduğu görülmektedir. Öğretmelerin bu konuda en çok dile getirdikleri görüş katılımın gönüllülük esasının olmaması yönündedir. Bu görüşün dile getirilen diğer görüşlere de temel teşkil ettiği düşünülmektedir. Başlangıçta gönüllülük esasının olmayışı iş yükünün daha istekli kişide toplanmasına ya da özverili çalışılmaması gibi durumlara neden olabilir. Nitekim kendi isteği değil zorlama ile yapılan işlerde başarı, motivasyon gibi olumlu durumların yaşanması daha az mümkün olabilir. Öğretmenlerdeki bu gönülsüzlük durumunu ise rehberlik ve bilgi eksikliğinden kaynaklanabileceği düşünülmektedir. Öğretmenlerin bir kısmı farklı sorunların sebebi olarak da bilgi ve deneyim eksikliklerini gösterdiği ifade edilebilir. Lisans düzeyinde proje yazma derslerinin nispeten yakın dönemlerde derslere eklenmiş olduğu düşünülünce öğretmenlere proje yazma üzerine seminer bilgilendirici toplantı düzenlenmemiş olması bu bilgisizliğin beraberinde gönülsüzlüğü getirmiş olabilir. Sözer (2017) çalışmasında öğretmenlerin bilgi eksikliği ve çeşitli yönlerden desteğe ihtiyaç duyduklarını paylaşmıştır. Bulunuz (2011) da öğretmen bilgisizliğinin çeşitli sorunlara yol açtığını ifade etmiştir.

Sosyal bilgiler öğretmenlerinin TÜBITAK 4006 projesinde uygulama sırasında yaşadıkları sorunlar incelendiğinde öğretmenler tarafından öğrencilerin sunum becerilerinin yeterli görülmediği, proje uygulama süre ve maddi olanak kaynaklı sorun yaşadığı, öğretmenlerin iş birliği açısından sorun yaşadığı ifade edilebilir. Öğretmenlerin öğrencilerin sunum becerilerini yeterli görmemesinde öğrencilerin yaşadığı heyecan ve daha önce sunum deneyimlerinin olmayışından kaynaklı ifade sorunları nedeniyle öğretmenlerin bu görüşe sahip olduğu düşünülmektedir. Öğretmenlerin proje katkısı olarak dile getirdikleri görüşler de bu fikri destekler niteliktedir. Çalışmanın bu sonucunun literatürle paralel olduğu söylenebilir. Yine çalışmadan elde edilen ve öğretmenlerin proje uygulaması sırasında maddi olanak kaynaklı sorunlarının literatürle paralel olduğu söylenebilir. Tortop (2013) yaptığı çalışmada öğretmenlerin proje çalışmalarında maddi yetersizlik ve ulaşım sorununu yaşadığı sonucunu paylaşmıştır. Çalışmadan elde edilen bir diğer sonuç öğretmenlerin iş birliği konusunda 
sorun yaşadığıdır. Öğretmelerin iş yükünün bir kişide toplandığını, rehber ve destek bulamadıkları için sorun yaşadıklarını dile getirmeleri nedeniyle iş birliği konusunda sorun yaşadıkları söylenebilir.

Sosyal bilgiler öğretmenlerinin TÜBITAK 4006 projesinin değerlendirme sürecinde karşılaştıkları sorunlar incelendiğinde sergiye katılımın yeterli görülmediği, projelerin nitelik açısından değil nicel olarak değerlendirildiği, zaman-maaliyet konusunda sorun yaşandığı söylenebilir. Elde edilen bu sonuçlar literatürle uyuşmaktadır. Nitekim yaptığı çalışmada Tortop (2013) sonuçlarını paylaşmıştır. Ayrıca öğretmenlerin materyal oluşturma adına sorun yaşadığı ve daha az model-maket yapımı tercih ettikleri, fen-matematik ağılıkı model-maketlerin dikkat çekmesinden rahatsız oldukları ifade edilebilir. Materyal oluşturma adına yaşanan sorun maddi kaynaklı olması Kankelborg' un (2005) çalışmasıyla paralel nitelikte olmakla beraber sosyal bilgilerin doğasından ötürü her konunun maket- model yapımına elverişli olmaması sorun olduğu düşünülmektedir. Öğretmenlerin hem yönetim hem de program kaynaklı sorunları daha yoğun yaşadıkları ifade edilebilir. Öğretmenlerin ders yoğunluğu projeye katılımlarından değerlendirme sürecine kadar birçok basamakta dile getirilen bir husus olup öğretmenlerin projeye katılımlarını etkilediği düşünülmektedir. Bu husus literatürdeki benzer çalışmalarla da paralellik göstermektedir (Kankelborg, 2005).

Sosyal bilgiler öğretmenlerinin TÜBITAK 4006 projelerine dahil olmada motivasyon kaynağının çoğunlukla dışsal ve kurum kaynaklı olduğu söylenebilir. Öğretmenler öncelikle kurum yönlendirmesi ve öğrencilere katkı sağlayacağını düşündükleri için projeye dahil oldukları düşünülmektedir. Literatürde de bu çalışmanın sonuçları ile örtüşen çalışmalar bulunmaktadır. Czerniak ve Lumpe, 1996; Abernathy ve Vineyard, 2001; Oğuz Ünver vd. (2015) ve Fisanick (2010) yaptıkları çalışmada öğretmenlerin okul yönetiminin zorunlu tutması ya da beklenti içinde olması neticesinde proje çalışmalarına katıldıklarını ifade etmiştir. Bu durum öğrencilerin katıım durumlarında da dile getirilmiştir. Oysa Kosick (2009) yaptığı çalışmasında proje çalışmalarına katılımın zorunlu tutulması durumunun hem etik hem de işleyişte sorunlar çıkaracağını vurgulamaktadır. Bu çalışmada da bu durumun sorun olarak dile getirilen birçok bulgunun nedenini oluşturduğu düşünülmektedir.

Çalışmadan elde edilen sonuçlara göre sosyal bilgiler öğretmenleri TÜBiTAK 4006 proje sürecinin araştırmaya teşvik, dışsal motivasyon ve bilişsel ve duyuşsal beceri kazanma adına kendilerine fayda sağladığını düşünmektedir. Çalışmanın bu sonucunun literatürle paralellik gösterdiği söylenebilir. Bu bağlamda Atalmış, Selçuk ve Ataç (2018), Jensen ve Buckley (2014), Avcı vd. (2016), Küfrevioğlu, Baydaş ve Göktaş (2011), Çetin ve Şengezer (2016) ve Sözer (2017) yaptığı çalışmada proje süreçlerinin duyuşsal katkılarının olduğu bilgisini paylaşmıştır. Çalışmadan elde edilen bir diğer sonuca göre öğretmenlerden her ne kadar projelere gönüllü olarak katılım sağlamasalar da proje sürecinin kendilerine fayda sağladığını ifade edenlerin olduğu ve öğretmenlerin çoğunlukla bu süreci önyargısız değerlendirdiği söylenebilir.

Çalışmadan elde edilen sonuçlara göre sosyal bilgiler öğretmenleri TÜBiTAK 4006 proje sürecinin topluma en önemli katkısının toplum nazarında bilimin fark edilmesi olarak görmektedir. Bu bağlamda TÜBITAK 4006 projelerinin toplumla bilimin buluşması olarak değerlendirdikleri söylenebilir. Çalışmadan elde edilen bu sonucun Atalmış vd. (2018), Dionne vd. (2012) ve Oğuz Ünver, (2015) tarafından yapılan çalışmanın sonuçlarıyla örtüştüğü söylenebilir. Tortop (2013) yaptığı çalışmada ailelerin proje çalışmalarına karşı olumsuz tutum sergilediği sonucunu paylaşırken bu çalışmada Tortop'un çalışmasının aksine proje çalışmalarının öğretmenlere göre aile ve toplum tarafından ilgi gören etkinlikler olarak değerlendirildiği ifade edilebilir.

Çalışmadan elde edilen sonuçlara göre sosyal bilgiler öğretmenleri TÜBITAK 4006 proje sürecinin öğrencilere yönelik en önemli katkısının akademik ve duyuşsal olarak değerlendirdikleri 
söylenebilir. Öğretmenlerin proje sürecinin öğrencilere akademik beceri kazandırma adına faydalı olarak gördükleri ifade edilebilir. Bu bağlamda öğretmenlerin görüşleri ile TÜBiTAK 4006 proje amaçlarında yer alan hedeflerin örtüştüğü söylenebilir. Yine çalışmadan elde edilen bu sonuç literatürle paralellik göstermektedir. Nitekim Çavuş vd. (2018) ve Yıldııım (2018) yaptığı çalışmada proje süreçlerinin öğrencilerin problem çözme becerileri üzerinde etkili bulunduğu, Grote (1995) ve Özel ve Akyol (2016) ise proje çalışmalarının öğrencilerin derse ilgisi ve bilime algıları üzerinde etkili olduğu sonucunu paylaşmıştır. Bruce ve Bruce (2000), Balas (2003) yaptıkları çalışmada proje çalışmalarının öğrencilerin bilime ilgi ve olumlu tutum geliştirmede önemli olduğunu ve proje çalışmalarının bilginin nasıl kullanılacağını gösterme adına proje çalışmalarının etkili olduğunu belirtmektedir. Aynı çalışmada proje çalışmalarının öğrencilerde bilgilerini deneyimleyerek geliştirmelerini sağladığı ifade edilmektedir. Akay (2013) yaptığı çalışmada da benzer olarak öğrencilerin proje çalışmalarıyla yaparak-yaşayarak öğrendikleri ve bu durum bilime olumlu düşünce geliştirmelerinde etkili olduğunu belirtmiştir. Bunderson ve Anderson (1996) ise yaptığı çalışmada proje sürecinin öğrencilerde özgüven ve iletişim becerisine katkı sağladığı sonucunu paylaşmıştır. Benzer şekilde Dionne vd. (2012); Oğuz Ünver vd. (2015) tarafından yapılan çalışmalarda proje süreçlerinin öğrenci üzerindeki akademik ve duyuşsal katıları dile getirilmiştir. Yine Bolat vd. (2014), Kubinova vd. (1999), Dionne vd. (2012) Küfrevioğlu vd. (2011), Jensen ve Buckley (2014), Avcı vd. (2016), Çetin ve Şengezer (2016) ve Sözer (2017), Benzer ve Evrensel (2019) yaptıkları çalışmada proje sürecinin çok yönlü katkılarının olduğu, öğretmen-öğrenci etkileşimini artırdığı, etraftaki sorunlara duyarlıı̆̆ı artırdığı, araştırma, işbirliği ve iletişim becerisi geliştirdiği, özgüven üzerinde etkili olduğu bilgisini paylaşmıştır. Durmaz vd., (2017), Finnerty (2013) ve Sülün vd. (2009) fen bilgisi özelinde yaptıkları çalışmada proje süreçlerinin öğrencilerin derse yönelik tutumlarında olumlu etkiye sahip olduğunu ifade etmiştir.

Çalışmadan elde edilen sonuçlar genel olarak değerlendirildiğinde sosyal bilgiler öğretmenlerinin 4006 proje sürecinde yaşadıkları alana özgü sorun ve literatürle örtüşmeyen birkaç başlı̆ı̆n bulunduğu ifade edilebilir. Konu seçme adına sosyal bilim konularının daha az yer aldığı, maket-model yapma konusunda yetersiz kalındığı ya da diğer derslerin bu bağlamda daha çok dikkat çektiği, sorunların dile getirildiği kadar çözüm sunulmadığı çalışmadan elde edilen dikkat çekici sonuçlardandır.

\section{Öneriler}

- $\quad$ Araştırma sonucundan hareketle okul yöneticilerinin öğretmenleri ve öğrencileri projeler konusunda teşvik etmedikleri görüşüne rastlanmıştır. Bu bağlamda okul yöneticilerinin, öğretmen ve öğrencileri proje çalışmalarına teşvik etmeleri daha nitelikli, orijinal ve amacına uygun projelerin hazırlanmasına zemin hazırlayabilir.

- Proje çalışmalarında görev alan öğretmenler görüşme esnasında yeterince vakitlerinin olmadığını ifade etmişlerdir. Bu yüzden öğretmenlerin ders yüklerinin azaltılması ve bunun yerine projeler için ayrı çalışma saatlerine yer verilmesi gibi adımların atılması daha verimli sonuçlar ortaya çıkartabilir.

- $\quad$ Proje hazırlığına başlanılmadan önce öğretmen ve öğrencilere bu süreçle ilgili eğitim verilmesi hazırlık, uygulama ve değerlendirme sürecinin daha etkin ve verimli geçmesini sağlayabilir.

- Görüşleri alınan sosyal bilgiler öğretmenleri tarafından TÜBiTAK'ın proje konularını belirlerken daha çok fen bilgisi, matematik, bilgisayar teknolojileri gibi alanların kazanımlarına ağırık verdiğinden sosyal bilgiler dersi kazanımlarına yeterli derecede yer vermediği ifade edilmiştir. Bu sebeple TÜBITAK projelerinde sosyal bilgiler dersine ve kazanımlara daha fazla yer verilmesi sosyal bilgiler ders içeriği anlamında öğrencilere olumlu katkılar sağlayabilir.

- $\quad$ Araştırma sonucunda öğretmenler maddi imkanlar kısıtlı olduğu için projelerini uygulanırken veya gerçekleştirirken sorunlar yaşadıklarını dile getirmişlerdir. Bu sebeple projelerin daha nitelikli sonuçlar doğurması için maddi açıdan destekler arttırılabilir. 
- $\quad$ Proje fikrinin oluşum ve uygulama aşamasına kadar süreci anlatan broşür, poster vb. yazılı doküman ve animasyon, kısa film gibi dijital materyaller ile öğretmen ve öğrenciler bilgilendirilebilir. Öğrencinin aktif katııımını sağlamak için proje rehberinde yer alan uyulması gereken hususlar ve konu başıkları öğrenci düzeyine uygun ve ilgi çekici olarak aktarılabilir.

- $\quad$ Alanında uzman personel ve proje deneyimi olan kişilerle dijital ortamda buluşmayı sağlayan resmi bir platform kurulabilir. Böylece proje fikri oluşturma, yazma ve uygulama gibi alanlarda sorun yaşayan öğretmen ve öğrencilerin farklı mekanlardaki kişilerle iletişim kurması sağlanabilir.

\section{Teşekkür}

Çalışmanın fikir aşamasından yazım aşamasına kadar tüm aşamalarda desteğini esirgemeyen değerli Prof. Dr. Ayşegül ŞEYịHOĞLU'na teşekkürlerimizi sunarız. 


\section{Kaynakça}

Akay, C. (2013). Ortaokul öğrencilerinin TÜBiTAK “4004 yapıyorum öğreniyorum yaz bilim okulu” projesi sonrası bilim kavramına yönelik görüşleri. Mersin Üniversitesi Eğitim Fakültesi Dergisi, 9(2).

Abernathy, T.V., ve Vineyard, R.N. (2001). Academic competitions in science. Clearing House, 74(5), 269-277

Arı, A. (2010). Öğretmenlere göre proje ve performans görevlerinin uygulanmasında karşılaşılan sorunlar. Elektronik Sosyal Bilimler Dergisi, 9(34): 50-52.

Atalmış, E. H., Selçuk, G. ve Ataç, A. (2018). TUBiTAK 4006 projelerine ilişkin yönetici, yürütücü ve öğrenci görüşleri, Kırşehir Eğitim Fakültesi Dergisi, 19(3), 1999-2020.

Avcı, E., Su Özenir, Ö. \& Yücel, E. (2016). TÜBіTAK ortaöğretim öğrencileri araştırma projeleri yarışmasına katılan öğrencilerin yarışma sonrası kazanımlarının incelenmesi. Uşak Üniversitesi Sosyal Bilimler Dergisi, 9(27/3), 1-21.

Aydın, M., ve Çepni, S. (2011). Effectiveness of a Professional Support Program Related to Project Based Instruction (PBI) on Science and Technology Teachers' Needs. Journal of Turkish Science Education, 8(4), 55-68.

Bacanak, A., Aydın, M., \& Çepni, S. (2013). Fen ve teknoloji öğretmenlerinin proje tabanlı öğretim yöntemi (PTÖY) ile ilgili ihtiyaçlarının incelenmesi. Necatibey Eğitim Fakültesi Elektronik Fen ve Matematik Eğitimi Dergisi, 7(1), 1-31.

Baki, A., ve Bütüner, S. Ö. (2009). Kırsal Kesimdeki Bir Illköğretim Okulunda Proje Yürütme Sürecinden Yansımalar. Illkogretim Online, 8(1).

Balas, A.K. (1998, updated 2003). Science fairs in elementary school. (ERIC Document Reproduction Service No. ED 432444)

Benzer, S., ve Evrensel, E. (2019). тÜBіTAK 4006 bilim fuari hakkinda öğrenci görüşleri. Journal of Steam Education, 2(2), 28-38.

Bolat, A., Bacanak, A., Kaşıkçı, Y., ve Değirmenci, S. (2014). Bu benim eserim proje çalışması hakkında öğretmen ve öğrenci görüşleri. Eğitim ve Öğretim Araştırmaları Dergisi, 3(4), 100-110

Bruce, S.P., ve Bruce, B.C. (2000). Constructing images of science: People, technologies, and practices. Computers in Human Behavior, 16, 241-256.

Bulunuz, M. (2011). Fen Bilgisi Öğretmen Adaylarının Geçmiş Öğretim Kademelerindeki Bilimsel Araştırma Projesi Deneyimlerinin Değerlendirilmesi. Türk Fen Eğitimi Dergisi, Yıl 8, Sayı 4, Aralık 2011.

Bunderson, E. D., ve Anderson, T. (1996). Preservice Elementary Teachers' Attitudes Toward Their Past Experience With Science Fairs. School Science and Mathematics, 96(7), 371-377. http://doi.org/10.1111/j.1949-8594.1996.tb15855.x

Czerniak, C.M., ve Lumpe A.T. (1996). Predictors of science fair participation using the theory of planned behavior. School Science \& Mathematics, 97(7), 335-362

Çavuş, R., Balçın, M. D., ve Yılmaz, M. M. (2018). Bilim Fuarı Etkinliklerinin Ortaokul Öğrencilerinin Fen ve Problem Çözme Becerilerine Yönelik Algılarına Etkisi. Inönü Üniversitesi Eğitim Bilimleri Enstitüsü Dergisi, 5(10): 1-17.

Çelikkaya, T., ve Kuş, Z. (2009). Sosyal bilgiler öğretmenlerinin kullandıkları yöntem ve teknikler. Uludağ Üniversitesi Eğitim Fakültesi Dergisi, 22(2), 741-758.

Çepni, S. (2014). Araştırma ve Proje Çalışmalarına Giriş (7.Baskı), Trabzon.

Çetin, O., Şengezer, B. (2013). Ortaokul Öğrencilerinin Proje Çalışmalarına İlişkin Görüşleri. Ege Eğitim Dergisi, (14) 1, 24-49

Dionne, L., Reis, G., Trudel, L., Guillet, G., Kleine, L., ve Hancianu, C. (2012). Students' Sources of Motivation for Participating in Science Fairs: An Exploratory Study within the Canada-Wide Science Fair 2008. International Journal of Science and Mathematics Education, 10(3), 669-693. Retrieved from http://eric.ed.gov/?id=EJ968021

Durmaz, H., Oğuzhan-Dinçer, E., ve Osmanoğlu, A. (2017). Bilim şenliğinin öğretmen adaylarının fen öğretimine ve öğrencilerin fene yönelik tutumlarına etkisi. Trakya Üniversitesi Eğitim Fakültesi Dergisi, 7(2), 364378.

Eskici, M. (2017). Okul yöneticilerinin yapılandırmacı yaklaşım temel alınarak geliştirilen öğretim programlarının uygulanmasına yönelik görüşleri. Inönü Üniversitesi Eğitim Fakültesi Dergisi, 18(2), 16-32.

Fallik, O., Eylon, B. S., ve Rosenfeld, S. (2008). Motivating teachers to enact free-choice project-based learning in science and technology (PBLSAT): Effects of a professional development model. Journal of Science Teacher Education, 19(6), 565-591. 
Finnerty, V. (2013). Can Participation in A School Science Fair Improve Middle School Students' Attitudes Toward Science and Interest in Science Careers? Unpublished doctoral dissertation, University of Massachusetts Lowell. UMI Number: 3570455

Fisanick, L. M. (2010). A Descriptive Study Of The Middle School Science Teacher Behavior For Required Student Partıcipation In Science Fair Competitions (Yayınlanmamış doktora tezi). Indiana University of Pennsylvania, ABD.

Grote, M. (1995). Teacher opinions concerning science projects and science fairs. Ohio Journal of Science, 95(4), 274-277.

Güven, İ. (2013). Fen ve teknoloji öğretmen adaylarının proje yönetimi deneyimlerinin değerlendirilmesi [Evaluation of prospective science and technology teachers' experiences of project management in Turkish][Special Issue]. Hacettepe University Journal of Education, 1, 204-218.

Jensen, E., ve Buckley, N. (2014). Why people attend science festivals: Interests, motivations and self-reported benefits of public engagement with research. Public Understanding of Science, 23(5), 557-573.

Kankelborg, A., (2005). Rural science fair competition: levelling the playing field. Master thesis. Montana University, Montana. UMI: EP31005

Kececi, G. (2017). The Aims and Learning Attainments of Secondary and High School Students Attending Science Festivals: A Case Study. Educational Research and Reviews, 12(23), 1146-1153.

Kubinova, M., Novotna, J., \& Littler, G. H. (1999). Projects and mathematical puzzles-a tool for development of mathematical thinking.(Ed: Inge Schwank) European Research in Mathematics Education I, II: Group 5.

Küfrevioğlu, R. M., Baydaş, Ö., ve Göktaş, Y. (2011, September). Proje ve beceri yarışmalarında elde edilen kazanımlar, karşılaşılan sorunlar ve öneriler. In 5th International Computer \& Instructional Technologies Symposium (pp. 22-24).

Milli Eğitim Bakanlığı. (2018). Sosyal Bilgiler dersi öğretim programı. Ankara: Devlet Kitapları Basım Evi.

Oğuz Ünver, A., Arabacıoğlu, S. ve Okulu H. Z. (2015). “Öğretmenlerin Bu Benim Eserim Proje Yarışması Rehberlik Sürecine iliş̧kin Görüşleri”, MSKU Eğitim Fakültesi Dergisi, 2(2), 12-35.

Okuyucu, M.A. (2019). 4006-TÜBITAK Bilim Fuarına ilişkin öğretmen ve öğrenci görüşleri. International Journal of Social Sciences and Education Research, 5(2):202-218.

Özel, M. ve Akyol, C. (2016). Bu Benim Eserim Projeleri Hazırlamada Karşılaşılan Sorunlar, Nedenleri ve Çözüm Önerileri. Gazi Eğitim Fakültesi Dergisi, 36(1): 141-173.

Öztuna Kaplan, A., ve Diker Coşkun, Y. (2012). Proje tabanlı öğretim uygulamalarında karşılaşılan güçlükler ve çözüm önerilerine yönelik bir eylem araştırması. Mersin Üniversitesi Eğitim Fakültesi Dergisi, 8(1), 137-159.

Schneider, R.M., ve Lumpe, A.T. (1996). The nature of student science projects in comparison to educational goals for science. Ohio Journal of Science, 96(4/5), 81-88.

Sözer, Y. (2017). TÜBITAK ortaöğretim proje yarışmasına hazırlanan öğrencilerin proje geliştirme sürecinin incelenmesi: bir eylem araştırması. Inönü Üniversitesi Eğitim Fakültesi Dergisi, 18(2), 139-158. DOI: 10.17679/inuefd.334887

Sülün, Y., Ekiz, S. O., ve Sülün, A. (2009). Proje yarışmasının öğrencilerin fen ve teknoloji dersine olan tutumlarına etkisi ve öğretmen görüşleri. Erzincan Eğitim Fakültesi Dergisi Cilt-Sayı: 11-1, 75-94

Tortop, H.S. (2013). Science Teachers' Views about the Science Fair at Primary Education Level, Turkish Online Journal of Qualitative Inquiry, 4(2), 56-64.

Tortop, H.S. (2014). Examining of the Predictors of Pre-service Teachers' Perceptions of the Quality of the Science Fair Projects in Turkey, Necatibey Eğitim Fakültesi Elektronik Fen ve Matematik Eğitimi Dergisi, 8(1), 8, 31-44.

Web-1 https://bilimgenc.tubitak.gov.tr/makale/2019-2020-donemi-tubitak-4004-4005-ve-4007-programlaribasvurulari-basladi

Windschitl, M. (2003). Inquiry Projects in Science Teacher Education: What Can Investiga Experiences Reveal about Teacher Thinking and Eventual Classroom Practice? Science Education, 87(1), 112-143. http://doi.org/10.1002/sce.10044

Yıldırım, H. i. (2018). Bilim şenliklerinin ortaokul 6. sınıf öğrencilerinin problem çözme becerilerine etkisi. Trakya Üniversitesi Eğitim Fakültesi Dergisi, 8(2): 390-409.

Yıldırım, H. İ., ve Şensoy, Ö. (2016). Bilim şenliklerinin 6. sınıf öğrencilerinin fen bilimleri dersine yönelik tutumlarına etkisi. Türk Eğitim Bilimleri Dergisi, 14(1), 23-40.

Yıldırım, A., ve Şimşek, H. (2008). Sosyal Bilimlerde Bilimsel Araştırma Yöntemleri. Ankara: Seçkin Yayınevi 


\section{Etik Kurul Onay Bilgileri}

Çalışmanın etik kurul incelemesi Trabzon Üniversitesi Sosyal ve Beşeri Bilimler Bilimsel Araştırma ve Yayın Etik Kurulu tarafından yapılmış ve 19.02.2021 tarih "E-81614018-000-157" sayılı karar ile çalışmanın yapılması etik olarak uygun bulunmuştur. 